\title{
Marker-Assisted Introgression of Saltol QTL Enhances Seedling Stage Salt Tolerance in the Rice Variety "Pusa Basmati 1"
}

\author{
Vivek Kumar Singh, ${ }^{1}$ Brahma Deo Singh, ${ }^{2}$ Amit Kumar, ${ }^{1}$ Sadhna Maurya, ${ }^{3}$ \\ Subbaiyan Gopala Krishnan, ${ }^{1}$ Kunnummal Kurungara Vinod ${ }^{D},{ }^{4}$ Madan Pal Singh, ${ }^{3}$ \\ Ranjith Kumar Ellur, ${ }^{1}$ Prolay Kumar Bhowmick, ${ }^{1}$ and Ashok Kumar Singh $\mathbb{D}^{1}$ \\ ${ }^{1}$ ICAR-Indian Agricultural Research Institute, Division of Genetics, New Delhi 110012, India \\ ${ }^{2}$ Banaras Hindu University, School of Biotechnology, Varanasi 221005, Uttar Pradesh, India \\ ${ }^{3}$ ICAR-Indian Agricultural Research Institute, Division of Plant Physiology, New Delhi 110012, India \\ ${ }^{4}$ Rice Breeding and Genetics Research Centre, ICAR-Indian Agricultural Research Institute, Aduthurai 612 101, India
}

Correspondence should be addressed to Ashok Kumar Singh; aks_gene@yahoo.com

Received 29 August 2017; Revised 14 November 2017; Accepted 28 November 2017; Published 11 February 2018

Academic Editor: Gunvant B. Patil

Copyright (c) 2018 Vivek Kumar Singh et al. This is an open access article distributed under the Creative Commons Attribution License, which permits unrestricted use, distribution, and reproduction in any medium, provided the original work is properly cited.

\begin{abstract}
Marker-assisted selection is an unequivocal translational research tool for crop improvement in the genomics era. Pusa Basmati 1 (PB1) is an elite Indian Basmati rice cultivar sensitive to salinity. Here, we report enhanced seedling stage salt tolerance in improved PB1 genotypes developed through marker-assisted transfer of a major QTL, Saltol. A highly salt tolerant line, FL478, was used as the Saltol donor. Parental polymorphism survey using 456 microsatellite (SSR)/QTL-linked markers revealed 14.3\% polymorphism between PB1 and FL478. Foreground selection was carried out using three Saltol-linked polymorphic SSR markers RM8094, RM493, and RM10793 and background selection by 62 genome-wide polymorphic SSR markers. In every backcross generation, foreground selection was restricted to the triple heterozygotes of foreground markers, which was followed by phenotypic and background selections. Twenty-four near isogenic lines (NILs), with recurrent parent genome recovery of 96.0-98.4\%, were selected after two backcrosses followed by three selfing generations. NILs exhibited agronomic traits similar to those of PB1 and additional improvement in the seedling stage salt tolerance. They are being tested for per se performance under salt-affected locations for release as commercial varieties. These NILs appear promising for enhancing rice production in salinity-affected pockets of Basmati Geographical Indication (GI) areas of India.
\end{abstract}

\section{Introduction}

Rice plants suffer severe salt injury in both seedling and reproductive stages; the most common damages are attributed to osmotic imbalance, membrane destabilisation, and failure of photosynthetic machinery [1]. The damage due to salt stress is often cumulative as the seedling stage sensitivity leads to poor crop establishment, and reproductive stage sensitivity results in reduced yields [2]; the combined effect of damages at both the stages may lead to total crop loss. Nevertheless, seedling stage tolerance can sustain crop production in salinity prone areas by promoting good initial establishment leading to healthy vegetative growth that can augment crop yield [3]. There are some saline ecosystemadapted traditional rice landraces such as Pokkali and Nona Bokra that are known to be salt tolerant. Salt tolerance in rice is manifested through morphological, physiological, and metabolic responses that includes stomatal changes, sodium exclusion, tissue tolerance, apoplastic salt compartmentalization, salt sequestration into older tissues, and regulation of the antioxidants [2-5]. Apart from the understanding of physiological and metabolic responses to salt stress, quantitative trait loci (QTLs) and genes governing salt tolerance have also been reported in rice. These include a major QTL, Saltol 
identified on chromosome 1 of Pokkali, and SKC1 (OsHKT1;5), a gene located within the Saltol region identified from Nona Bokra. The QTL Saltol imparts salt tolerance by regulating $\mathrm{Na}^{+} / \mathrm{K}^{+}$homeostasis under salt stress [6-9].

In India, of the estimated area of 7.0 million ha (mha) occupied by saline soils, a sizeable fraction occurs in the Indo-Gangetic plains covering the states of Haryana, Punjab, Uttar Pradesh, Rajasthan, and Bihar [10]. Basmati rice is exclusively grown in an area of over 1.68 mha spanning the Indo-Gangetic plains; this region is recognised as its Geographical Indication (GI) area [11-14]. In recent times, soil salinity has become a major problem affecting Basmati rice cultivation, especially in the state of Haryana [11]. Haryana has about 1.0 mha under Basmati rice, majority of which is threatened by inland salinity resulting from the continuous use of brackish irrigation water [12]. None of the popular Basmati cultivars is reported to be tolerant to salt stress.

Basmati rice is preferred globally for its aromatic grains with unparalleled cooking qualities [11] such as extra-long slender grains, rich aroma, white kernels, translucent endosperm, high cooking elongation, fluffy cooked kernels, good palatability, and medium amylose content. Commercially released in 1989 by ICAR-Indian Agricultural Research Institute (ICAR-IARI), Pusa Basmati 1 (PB1) is the first semidwarf and high-yielding Basmati variety in the world. The release of $\mathrm{PB} 1$ revolutionized Basmati rice production in India, because of several advantages over the traditional Basmati cultivars: (a) It had an average yield of more than $4.5 \mathrm{t} /$ ha, as against the low average yield of $2.5 \mathrm{t} /$ ha for the traditional cultivars; (b) PB1 was shorter with robust plant stature, and (c) PB1 matured faster than the late and photosensitive traditional Basmati cultivars $[15,16]$. Soon after the release, PB1 got established as a premium cultivar and was extensively cultivated. Twenty-eight years after its commercial release, even today, $\mathrm{PB} 1$ is cultivated in about $0.16 \mathrm{mha}$ ( $\sim 10 \%$ of the total Basmati area) in India. It is used extensively in Basmati rice improvement programmes as donor for quality traits as well as high yield. However, PB1 is sensitive to several biotic stresses such as diseases (bacterial blight, blast, sheath blight, and bakanae) and pests (brown plant hopper) and also to abiotic stresses, such as soil salinity and drought. PB1 has been improved for resistance to bacterial blight [17], blast [18], and sheath blight [19] using molecular markers as indirect selection tools, but improvement of salinity tolerance of PB1 is yet to be achieved.

In recent times, marker-aided selection (MAS) has been widely acclaimed as the most effective method of transferring desirable traits $[1,8,20-22]$ in rice, including salinity tolerance. The conventional breeding efforts for salinity tolerance in rice had limited success, possibly due to their long turnover time, cumbersome screening procedures, and complex genetic control of the trait [1]. For transferring seedling stage salt tolerance, Saltol QTL is the only best-known target locus that is amenable to MAS. As the donor for Saltol, FL478 (IR 66946-3R-178-1-1), a highly salt tolerant RIL derived from the cross IR29/Pokkali, has been successfully deployed in breeding programmes in many countries. The SSR markers RM3412, AP3206, and RM8094 are used for transfer of Saltol $[11,23-26]$. Since grain quality traits are of paramount importance, MAS in Basmati rice needs special attention, especially when the transferred gene(s)/QTL(s) are sourced from non-Basmati donors [27, 28]. The Saltol donor, FL478, is a non-Basmati line that has grain characteristics such as medium bold shape, red pericarp, chalky endosperm, no aroma, high amylose content, and low gel consistency. The recovery of grain quality is achieved by integrating phenotypic selection for these traits, in every MAS stage [11].

In this paper, we report marker-aided introgression of the QTL Saltol from FL478 into PB1 and the resulting improvement in seedling stage salt tolerance of the PB1 near isogenic lines (NILs). Other agronomic features and grain quality of the NILs were comparable to those of the recurrent parent, PB1.

\section{Materials and Methods}

2.1. Plant Materials. The parents used in the present study were (a) PB1, as the recurrent parent (RP), and (b) FL478, as the donor parent for Saltol. FL478 is a breeding line with very high level of seedling stage salt tolerance; it can endure salt solutions with electrical conductivity (EC) of up to 15 $\mathrm{dSm}^{-1}$ for more than a fortnight. Both the parents were first evaluated for tolerance to $100 \mathrm{mM} \mathrm{NaCl}$ solution (EC of 11.6 $\mathrm{dSm}^{-1}$ ) at seedling stage to validate their salt tolerance levels before initiating the crossing programme. Salt tolerance was scored using the standard evaluation system (SES) for rice developed by the International Rice Research Institute, Manila, Philippines [29, 30]. In the pre-screening, the recurrent parent, $\mathrm{PB} 1$, was found highly sensitive to salt stress and recorded a score of nine, while the donor parent, FL478, was tolerant and recorded a score of one (Supplementary Figure 1). Crosses were made at IARI-Rice Breeding and Genetics Research Centre, Aduthurai, Tamil $\mathrm{Nadu}$ (IARI-RBGRC), and subsequent generations were shuttled between the ICAR-IARI, New Delhi, during Kharif season and IARI-RBGRC during off-season.

2.2. Breeding Strategy. PB1 was crossed as the female parent with FL478, and the hybridity of the $F_{1}$ plants was confirmed using the SSR marker, RM493. The confirmed $F_{1}$ s were backcrossed to PB1 (always used as the female parent in backcrosses) to generate the $B C_{1} F_{1}$ seeds. The plant selected in $F_{1}$ was designated as Pusa 1822; the lines derived from the backcross programme (Figure 1) carried the designation as the prefix, for example, Pusa 1822-6-14-9. The parental lines were screened for polymorphism at the target QTL locus using twenty-one Saltol-linked SSR markers, of which three markers RM8094, RM493, and RM10793 were found to be polymorphic (Supplementary Figure 2); all the three markers were used for foreground selection. Further, the genome-wide polymorphism between the parents was tested using 435 SSR markers, which identified 62 polymorphic markers that were employed for background selection (Supplementary Table 1). In the $B C_{1} F_{1}$ generation, the plants that tested positive for the three markers used for foreground selection were screened with the 62 SSR markers and subjected to phenotypic evaluation for agronomic traits, including grain characteristics. The plant with the highest recurrent 


\begin{tabular}{|c|c|c|}
\hline PB1 $q$ & & Rabi 2011-12 \\
\hline Kharif 2012 & & $\begin{array}{l}\text { Foreground selection: } 5 \mathrm{~F}_{1} \text { plants showed true hybridity } \\
\text { Selection: one } \mathrm{F}_{1} \text { plant for backcross: Pusa } 1822\end{array}$ \\
\hline PB1 $q$ & & Selected $F_{1}(1) \widetilde{\partial}$ \\
\hline Rabi 2012-13 & $\mathrm{BC}_{1} \mathrm{~F}_{1}$ & $\begin{array}{l}\text { Foreground selection: } 6 \text { plants out of } 20 \text { found positive for Saltol markers } \\
\text { RPG recovery: } 75.3 \% \text { to } 79.8 \% \\
\text { Selection (foreground + RPG + agronomic + grain traits): One plant, Pusa } \\
1822-6\end{array}$ \\
\hline $\mathrm{PB} 1 \uparrow$ & & Selected $\mathrm{BC}_{1} \mathrm{~F}_{1}(1) \sigma^{\star}$ \\
\hline Kharif 2013 & $\mathrm{BC}$ & $\begin{array}{l}\text { Foreground selection: } 14 \text { plants out of } 70 \text { found heterozygous for Saltol locus } \\
\text { RPG recovery: } 86.3 \% \text { to } 89.5 \% \\
\text { Selection (foreground + RPG + agronomic + grain traits): } 6 \text { plants }\end{array}$ \\
\hline & & $\begin{array}{l}\text { Foreground selection: } 11 \text { plants selected out of } 60 \text { plants } \\
\text { Phenotypic evaluation agronomic traits): } 11 \text { plants }\end{array}$ \\
\hline Rabi 2013-14 & & $\begin{array}{l}\text { RPG recovery: } 89.51 \% \text { to } 92.74 \% \\
\text { Grain quality selection: all } 11 \text { plants found comparable to PB1 }\end{array}$ \\
\hline Kharif 2014 & $\mathrm{BC}$ & $\begin{array}{l}\text { Salt tolerance selection: one family, Pusa } 1822-6-14-9 \text { out of } 11 \text { families } \\
\text { Phenotypic selection (agronomic traits): } 24 \text { plants } \\
\text { Foreground selection: all } 24 \text { plants reconfirmed for the presence of Saltol } \\
\text { RPG recovery: } 96.0 \% \text { to } 98.4 \% \\
\text { Grain quality selection: all } 24 \text { lines found similarto PB1 } \\
\text { Salt tolerance selection: all } 24 \text { NILs are salt tolerant }\end{array}$ \\
\hline Kharif 2015 & $\mathrm{BC}_{2} \mathrm{~F}_{4}$ & Agronomic evaluation of 24 NILs-station trial \\
\hline
\end{tabular}

FIGURE 1: Breeding scheme used in the marker-assisted backcross programme for the transfer of Saltol locus in the background of the elite rice variety, Pusa Basmati 1.

parent genome (RPG) recovery, and having most similarity to the RP, was backcrossed to $\mathrm{PB} 1$ to produce the $B C_{2} F_{1}$ seeds. The $B C_{2} F_{1}$ plants were handled in the same manner, except for using only those markers for background selection that were heterozygous in $B C_{1} F_{1}$. The selected $B C_{2} F_{1}$ plants were selfed to produce $B C_{2} F_{2}$ generation. Each $B C_{2} F_{2}$ plant was subjected to foreground selection to identify plants homozygous for all the three foreground markers. The selected plants were subjected to background and phenotypic selections, the former to assess the recovery of RPG, using markers that were heterozygous in $B C_{2} F_{1}$, and the later to determine the recovery of Basmati quality traits. The selected $B C_{2} F_{2}$ plants were selfed to raise $B C_{2} F_{3}$ families, which were screened for seedling stage salt tolerance. The family showing the highest level of salt tolerance was transplanted in the field and evaluated for agronomic performance and grain quality. Agronomically superior members of the tolerant family were subjected to foreground screening to confirm the presence of Saltol alleles in homozygous state and background selection based on markers that were heterozygous in $B C_{2} F_{2}$ family to assess further increase in the
RPG recovery. The salt tolerant lines were advanced to $\mathrm{BC}_{2} \mathrm{~F}_{4}$ generation.

2.3. Molecular Analyses. Genomic DNA was isolated from young leaves of the test lines when they were about 40 days old using the standard Cetyl Trimethyl Ammonium Bromide protocol [31]. Polymerase chain reaction- (PCR-) based amplification of the target genomic fragments by the primer pairs for each selected marker was performed in a $10 \mu \mathrm{l}$ reaction mix constituted by adding 25-30 ng genomic DNA, $5 \mathrm{pmol}$ each of the two primers, $0.05 \mathrm{mM}$ each of the four dNTPs, and PCR buffer $(10 \mathrm{x})$ containing $10 \mathrm{mM}$ Tris ( $\mathrm{pH} 8.4$ ), $50 \mathrm{mM} \mathrm{KCl}$, and $1.8 \mathrm{mM} \mathrm{MgCl}_{2}$. To this mix, $0.5 \mathrm{U}$ of Taq DNA polymerase was added, and the volume made up to $10 \mu \mathrm{l}$ using nuclease free water. The PCR was run for 35 cycles comprising of denaturation for one minute at $94^{\circ} \mathrm{C}$, followed by annealing for one minute at $55^{\circ} \mathrm{C}$, and primer elongation for two minutes at $72^{\circ} \mathrm{C}$, sandwiched between an initial denaturation for five minutes at $94^{\circ} \mathrm{C}$ and the final extension for seven minutes at $72^{\circ} \mathrm{C}$. The amplified products were electrophoresed in $3.5 \%$ agarose gel, and the 
products were visualized using a gel documentation system. The marker segregation data was graphically compiled in each generation using Graphical GenoTypes (GGT) version 2.0 software [32].

2.4. Marker-Aided Selection. Details of three Saltol-linked SSR markers, RM8094, RM493, and RM10793, used for foreground selection such as their physical position on chromosome 1, primer nucleotide sequences, and physical locations within the Saltol QTL are given in Supplementary Table 2. The details of all the genome-wide polymorphic SSR markers used for assessing the background polymorphism were sourced from the rice marker database at Gramene (http:// www.gramene.org). In each backcross generation, background selection was done after foreground and phenotypic selections. In the background selection process using 62 polymorphic markers, the number of plants with homozygous alleles similar to PB1 and heterozygotes was counted sepa-
TABLE 1: Genetic diversity between the recurrent parent PB1 and the Saltol donor FL478. The foreground survey was limited to Saltol region alone, whereas the background survey included all chromosomes, including the Saltol carrier chromosome 1.

\begin{tabular}{lccc}
\hline Class of markers & $\begin{array}{c}\text { Markers } \\
\text { surveyed }\end{array}$ & $\begin{array}{c}\text { Polymorphic } \\
\text { markers }\end{array}$ & $\begin{array}{c}\text { Polymorphism } \\
(\%)\end{array}$ \\
\hline Foreground & 21 & 3 & 14.29 \\
Background* & 435 & 62 & 14.75 \\
${\text { Chromosome } 1^{\S}}^{\S}$ & 63 & 7 & 11.11 \\
\hline
\end{tabular}

* includes markers on chromosome 1, excluding Saltol-linked markers;

${ }^{\S}$ Based on all markers used including Saltol-linked markers.

rately for each marker. A reductionist strategy was followed for background selection; markers that became homozygous for the PB1 allele in a given generation were not included in the assay for the subsequent generations. RPG recovery was computed using following formula:

$$
\mathrm{RPG} \text { recovery } \%=\left[\frac{\text { number of marker homozygous for } \mathrm{RP} \text { alleles }+(0.5 \times \text { number of heterozygotes markers })}{\text { total number of polymorphic markers }}\right] \times 100
$$

To ensure maximum recovery of the carrier chromosome of the Saltol QTL, the chromosome 1 was surveyed with 42 evenly distributed SSR markers together with 21 markers linked to the Saltol region. Complete recovery of the chromosome 1 together with Saltol was specifically targeted, while exercising selections for the background genome.

\subsection{Screening for Seedling Stage Salt Tolerance. The PB1 NILs} homozygous for the Saltol QTL along with the two parents were screened for seedling stage salt tolerance at the National Phytotron Facility, ICAR-IARI, New Delhi. Average day/ night temperature of approximately $32 / 25^{\circ} \mathrm{C}$ and relative humidity of $70-80 \%$ were maintained at the screen house throughout the study period. Polystyrene floats with a $14 \times 8$ matrix of holes lined with a nylon net at the bottom side, and suspended in plastic crates filled with 10 litres of Yoshida nutrient solution $[1,33]$, were used for screening. The experiment was set up according to a randomized complete block design with two treatments $(0.0 \mathrm{mM}$ as control and $100 \mathrm{mM}$ (EC of $11.6 \mathrm{dSm}^{-1}$ ) $\mathrm{NaCl}$ for salt stress) and three replications. Each replication comprised two plastic crates, one crate having six plants each of 12 NILs and the parents PB1 and FL478. The parents served as susceptible and salt tolerant checks. Four-day-old pregerminated seeds were surface sterilized using 70\% ethanol and 5\% sodium hypochlorite for five minutes each, transferred into the holes in the polystyrene floats, and allowed to germinate over the nutrient solution. The seedlings were subjected to salinity stress after 14 days, starting with an EC of $3 \mathrm{dSm}^{-1}$ by adding $26 \mathrm{mM} \mathrm{NaCl}$ concentration in the nutrient solution, and subsequently elevating to $11.6 \mathrm{dSm}^{-1}(100 \mathrm{mM} \mathrm{NaCl})$ three days after. The same volume of deionized water was added in the control set. The nutrient solution was replaced once a week, and its $\mathrm{pH}$ was maintained daily at 5.8 (adjusted by adding either $1 \mathrm{~N} \mathrm{NaOH}$ or $\mathrm{HCl}$ ). The $\mathrm{EC}$ of the nutrient solution was recorded daily. Sixteen days after imposing the full salt stress, the symptoms were scored as per SES for rice [30]. The genotypes showing score of 1-3 were classified as tolerant, those with a score of 5 were moderately tolerant, and those with scores of 7-9 were rated as susceptible.

2.6. Agronomic and Grain Quality Assessment. Agronomic evaluation of the $B C_{2} F_{4}$ NILs along with both the parents was carried out during Kharif 2015 at the research farm of the Division of Genetics, ICAR-IARI, New Delhi, in a field trial laid out in a randomized complete block design with two replications and plot size of $5 \mathrm{~m}^{2}$. Twenty-five-day-old seedlings were transplanted at a spacing of $20 \mathrm{~cm} \times 15 \mathrm{~cm}$, and the trial was maintained adopting recommended agronomic practices. From each replication, data on various agronomic traits, namely, days to $50 \%$ flowering (DFF), plant height $(\mathrm{PH})$, effective tillers per plant (ETP), panicle length (PL), spikelet fertility (SF), weight of 1000 grains (TW), and grain yield per plant (YLD), were recorded from five random plants selected from each entry. The harvested grains from the NILs and their parents were assessed for quality traits like hulling recovery (HUL), milling recovery (MIL), and cooking-related characters, such as kernel length before and after cooking (KLBC and KLAC, resp.), kernel elongation on cooking (ER), alkali spreading value (ASV), and aroma (AROM) as described earlier [34].

2.7. $\mathrm{Na}^{+}$and $\mathrm{K}^{+}$Contents in Shoots and Roots. Since Saltol acts by balancing the $\mathrm{Na}^{+}$and $\mathrm{K}^{+}$ions in the plant system to counter the salt stress, we estimated the cationic concentrations in shoots and roots from the salt-stressed and salt- 
TABle 2: Agronomic performance, salt tolerance, and recurrent parent genome recovery of Saltol-introgressed NILs of Pusa Basmati 1.

\begin{tabular}{|c|c|c|c|c|c|c|c|c|c|c|c|c|}
\hline \multirow{2}{*}{ NILS } & \multicolumn{8}{|c|}{ Agronomic traits } & \multicolumn{4}{|c|}{ RPG recovery } \\
\hline & DFF & $\mathrm{PH}$ & ETP & PL & SF & TW & YLD & STS & $\mathrm{RP}$ & HT & $\mathrm{DP}$ & RPG \% \\
\hline NIL1 & $101.0^{\mathrm{a}-\mathrm{e}}$ & $97.7^{\mathrm{a}}$ & $20.7^{\mathrm{ab}}$ & $27.8^{\mathrm{a}}$ & $77.4^{\mathrm{ab}}$ & $19.4^{\mathrm{a}}$ & $43.6^{\mathrm{a}}$ & 1.0 & 60 & 1 & 1 & 97.58 \\
\hline NIL2 & $98.5^{\mathrm{c}-\mathrm{e}}$ & $93.3^{\mathrm{a}}$ & $17.7^{\mathrm{ab}}$ & $28.4^{\mathrm{a}}$ & $70.8^{\mathrm{ab}}$ & $19.4^{\mathrm{a}}$ & $43.4^{\mathrm{a}}$ & 1.0 & 60 & 1 & 1 & 97.58 \\
\hline NIL3 & $97.0^{\mathrm{de}}$ & $86.7^{\mathrm{a}}$ & $14.6^{\mathrm{ab}}$ & $25.3^{\mathrm{a}}$ & $71.0^{\mathrm{ab}}$ & $16.5^{\mathrm{a}}$ & $38.7^{\mathrm{a}}$ & 1.0 & 59 & 2 & 1 & 96.77 \\
\hline NIL4 & $106.0^{\mathrm{a}}$ & $86.0^{\mathrm{a}}$ & $14.1^{\mathrm{ab}}$ & $27.2^{\mathrm{a}}$ & $81.7^{\mathrm{a}}$ & $19.9^{\mathrm{a}}$ & $38.3^{\mathrm{a}}$ & 1.0 & 60 & 1 & 1 & 97.58 \\
\hline NIL5 & $105.0^{\mathrm{a}-\mathrm{c}}$ & $88.9^{\mathrm{a}}$ & $15.1^{\mathrm{ab}}$ & $26.5^{\mathrm{a}}$ & $74.1^{\mathrm{ab}}$ & $17.8^{\mathrm{a}}$ & $39.1^{\mathrm{a}}$ & 1.0 & 59 & 2 & 1 & 96.77 \\
\hline NIL6 & $106.0^{\mathrm{a}}$ & $95.6^{\mathrm{a}}$ & $14.9^{\mathrm{ab}}$ & $27.8^{\mathrm{a}}$ & $78.7^{\mathrm{ab}}$ & $19.8^{\mathrm{a}}$ & $38.5^{\mathrm{a}}$ & 1.0 & 59 & 2 & 1 & 96.77 \\
\hline NIL7 & $106.0^{\mathrm{a}}$ & $91.5^{\mathrm{a}}$ & $12.8^{\mathrm{b}}$ & $26.9^{\mathrm{a}}$ & $69.5^{\mathrm{ab}}$ & $19.9^{\mathrm{a}}$ & $39.0^{\mathrm{a}}$ & 1.0 & 60 & 1 & 1 & 97.58 \\
\hline NIL8 & $98.5^{\mathrm{c}-\mathrm{e}}$ & $93.7^{\mathrm{a}}$ & $18.9^{\mathrm{ab}}$ & $29.0^{\mathrm{a}}$ & $76.8^{\mathrm{ab}}$ & $18.9^{\mathrm{a}}$ & $40.2^{\mathrm{a}}$ & 1.0 & 60 & 1 & 1 & 97.58 \\
\hline NIL9 & $98.5^{\mathrm{c}-\mathrm{e}}$ & $93.8^{\mathrm{a}}$ & $14.3^{\mathrm{ab}}$ & $26.9^{\mathrm{a}}$ & $81.3^{\mathrm{a}}$ & $18.0^{\mathrm{a}}$ & $39.7^{\mathrm{a}}$ & 1.0 & 60 & 1 & 1 & 97.58 \\
\hline NIL10 & $99.0^{\mathrm{b}-\mathrm{e}}$ & $90.3^{\mathrm{a}}$ & $16.7^{\mathrm{ab}}$ & $25.2^{\mathrm{a}}$ & $79.2^{\mathrm{a}}$ & $19.1^{\mathrm{a}}$ & $38.9^{\mathrm{a}}$ & 1.0 & 59 & 2 & 1 & 96.77 \\
\hline NIL11 & $103.0^{\mathrm{a}-\mathrm{d}}$ & $95.0^{\mathrm{a}}$ & $17.6^{\mathrm{ab}}$ & $28.7^{\mathrm{a}}$ & $82.7^{\mathrm{a}}$ & $18.9^{\mathrm{a}}$ & $44.9^{\mathrm{a}}$ & 1.0 & 61 & 0 & 1 & 98.39 \\
\hline NIL12 & $103.0^{\mathrm{a}-\mathrm{d}}$ & $88.0^{\mathrm{a}}$ & $15.4^{\mathrm{ab}}$ & $27.5^{\mathrm{a}}$ & $78.0^{\mathrm{ab}}$ & $19.4^{\mathrm{a}}$ & $42.9^{\mathrm{a}}$ & 1.0 & 59 & 2 & 1 & 96.77 \\
\hline NIL13 & $99.0^{\mathrm{b}-\mathrm{e}}$ & $91.2^{\mathrm{a}}$ & $12.7^{\mathrm{b}}$ & $27.5^{\mathrm{a}}$ & $79.3^{\mathrm{a}}$ & $18.1^{\mathrm{a}}$ & $42.6^{\mathrm{a}}$ & 1.0 & 59 & 2 & 1 & 96.77 \\
\hline NIL14 & $105.0^{\mathrm{a}-\mathrm{c}}$ & $97.6^{\mathrm{a}}$ & $13.4^{\mathrm{ab}}$ & $27.7^{\mathrm{a}}$ & $76.5^{\mathrm{ab}}$ & $19.9^{\mathrm{a}}$ & $40.0^{\mathrm{a}}$ & 1.0 & 60 & 1 & 1 & 97.58 \\
\hline NIL15 & $105.5^{\mathrm{ab}}$ & $95.4^{\mathrm{a}}$ & $15.2^{\mathrm{ab}}$ & $27.2^{\mathrm{a}}$ & $77.6^{\mathrm{ab}}$ & $17.6^{\mathrm{a}}$ & $41.3^{\mathrm{a}}$ & 1.0 & 59 & 2 & 1 & 96.77 \\
\hline NIL16 & $100.5^{\mathrm{a}-\mathrm{e}}$ & $92.3^{\mathrm{a}}$ & $17.6^{\mathrm{ab}}$ & $25.1^{\mathrm{a}}$ & $75.8^{\mathrm{ab}}$ & $16.9^{\mathrm{a}}$ & $39.0^{\mathrm{a}}$ & 1.0 & 60 & 1 & 1 & 97.58 \\
\hline NIL17 & $102.0^{\mathrm{a}-\mathrm{d}}$ & $94.0^{\mathrm{a}}$ & $17.9^{\mathrm{ab}}$ & $25.8^{\mathrm{a}}$ & $72.9^{\mathrm{ab}}$ & $16.7^{\mathrm{a}}$ & $41.6^{\mathrm{a}}$ & 1.0 & 60 & 1 & 1 & 97.58 \\
\hline NIL18 & $99.0^{\mathrm{b}-\mathrm{e}}$ & $91.4^{\mathrm{a}}$ & $18.0^{\mathrm{ab}}$ & $27.0^{\mathrm{a}}$ & $78.8^{\mathrm{a}}$ & $17.5^{\mathrm{a}}$ & $41.2^{\mathrm{a}}$ & 1.0 & 60 & 1 & 1 & 97.58 \\
\hline NIL19 & $95.0^{\mathrm{e}}$ & $93.8^{\mathrm{a}}$ & $14.3^{\mathrm{ab}}$ & $26.0^{\mathrm{a}}$ & $78.3^{\mathrm{ab}}$ & $19.6^{\mathrm{a}}$ & $42.5^{\mathrm{a}}$ & 1.0 & 60 & 1 & 1 & 97.58 \\
\hline NIL20 & $98.5^{\mathrm{c}-\mathrm{e}}$ & $96.2^{\mathrm{a}}$ & $16.6^{\mathrm{ab}}$ & $27.1^{\mathrm{a}}$ & $80.2^{\mathrm{a}}$ & $18.0^{\mathrm{a}}$ & $40.3^{\mathrm{a}}$ & 1.0 & 61 & 0 & 1 & 98.39 \\
\hline NIL21 & $102.0^{\mathrm{a}-\mathrm{d}}$ & $100.6^{\mathrm{a}}$ & $22.5^{\mathrm{a}}$ & $27.4^{\mathrm{a}}$ & $73.3^{\mathrm{ab}}$ & $19.4^{\mathrm{a}}$ & $42.2^{\mathrm{a}}$ & 1.0 & 59 & 2 & 1 & 96.77 \\
\hline NIL22 & $106.0^{\mathrm{a}}$ & $99.7^{\mathrm{a}}$ & $17.7^{\mathrm{ab}}$ & $26.0^{\mathrm{a}}$ & $58.4^{\mathrm{b}}$ & $16.6^{\mathrm{a}}$ & $37.2^{\mathrm{a}}$ & 1.0 & 59 & 2 & 1 & 96.77 \\
\hline NIL23 & $100.0^{\mathrm{a}-\mathrm{e}}$ & $89.6^{\mathrm{a}}$ & $17.5^{\mathrm{ab}}$ & $27.0^{\mathrm{a}}$ & $78.6^{\mathrm{ab}}$ & $17.6^{\mathrm{a}}$ & $40.4^{\mathrm{a}}$ & 1.0 & 58 & 3 & 1 & 95.97 \\
\hline NIL24 & $104.0^{\mathrm{a}-\mathrm{c}}$ & $101.5^{\mathrm{a}}$ & $14.7^{\mathrm{ab}}$ & $28.1^{\mathrm{a}}$ & $76.2^{\mathrm{ab}}$ & $19.9^{\mathrm{a}}$ & $41.6^{\mathrm{a}}$ & 1.0 & 60 & 1 & 1 & 97.58 \\
\hline PB1 & $103.0^{\mathrm{a}-\mathrm{d}}$ & $98.9^{\mathrm{a}}$ & $18.4^{\mathrm{ab}}$ & $27.9^{\mathrm{a}}$ & $76.8^{\mathrm{ab}}$ & $19.5^{\mathrm{a}}$ & $43.3^{\mathrm{a}}$ & 9.0 & 100 & 0 & 0 & - \\
\hline FL478 & 83.5 & 97.0 & 13.0 & 25.0 & 85.5 & 26.2 & 45.5 & 1.0 & 0 & 0 & 100 & - \\
\hline CV (\%) & 1.56 & 5.52 & 13.80 & 4.00 & 6.50 & 6.85 & 5.36 & - & - & - & - & \\
\hline SE & 1.59 & 5.17 & 2.26 & 1.08 & 4.95 & 1.27 & 2.19 & - & - & - & - & \\
\hline
\end{tabular}

Means followed by same letters are statistically not different ( $p<0.05)$, by Tukey's honest significance test. DFF: days to $50 \%$ flowering; PH: plant height in $\mathrm{cm}$; ETP: effective tillers per plant; PL: panicle length in cm; TW: weight of 1000 grains in grams; YLD: yield in g per hill; STS: salt tolerance score (IRRI, 2013); RP: number of recurrent parent homozygotes; DP: number of donor parent homozygotes; HT: heterozygotes; RPG: recurrent parent genome recovery; CV: coefficient of variation; SE: standard error.

unstressed plants of the NILs and the parents [35]. The plant samples were prepared by carefully cleaning the shoots and roots and then drying them at $80^{\circ} \mathrm{C}$ for $24 \mathrm{~h}$. The dried samples were ground to fine powder in a rotary mill. $500 \mathrm{mg}$ of the powder was then digested in $10 \mathrm{ml}$ of diacid digestion mixture $\left(\mathrm{HNO}_{3}\right.$ and $\left.\mathrm{HClO}_{4}, 9: 4\right)$. The digest was cooled and washed into a volumetric flask, and the volume made up to $50 \mathrm{ml}$. The mixture was filtered with Whatman number 42 filter paper and analysed for $\mathrm{Na}^{+}$and $\mathrm{K}^{+}$using Systronics Type 128 flame photometer (Systronics India).

2.8. Statistical Analyses. The data were analysed for standard statistical tests using the software package Statistical Tools for Agricultural Research STAR 2.0.1 [36].

\section{Results}

3.1. Polymorphism between the Parents. Of the 21 Saltollinked markers tested, three markers, RM8094, RM493 and
RM10793, were found polymorphic between the parents. Further, four markers were found polymorphic among the 42 tested on the flanking regions of the Saltol, resulting in a cumulative polymorphism of $11.1 \%$ on chromosome 1 . Genome-wide polymorphism survey using 435 SSR markers (this included 42 markers tested on chromosome 1) identified a total of 62 polymorphic markers between PB1 and FL478, ranging from 4-7 markers spanned on each chromosome, resulting in an overall polymorphism of $14.7 \%$ between the parents (Table 1).

3.2. Development of Near Isogenic Lines by Marker-Assisted Selection. Five out of the $15 F_{1}$ plants from the cross PB1/ FL478 were found to be true $F_{1} \mathrm{~s}$ as they were heterozygous for the Saltol-linked marker RM493. One of the true $F_{1}$ plants was backcrossed with $\mathrm{PB} 1$ to produce $20 B C_{1} F_{1}$ plants. Foreground analysis using the three Saltol-linked markers identified six of the 20 plants to be heterozygous for all the three 


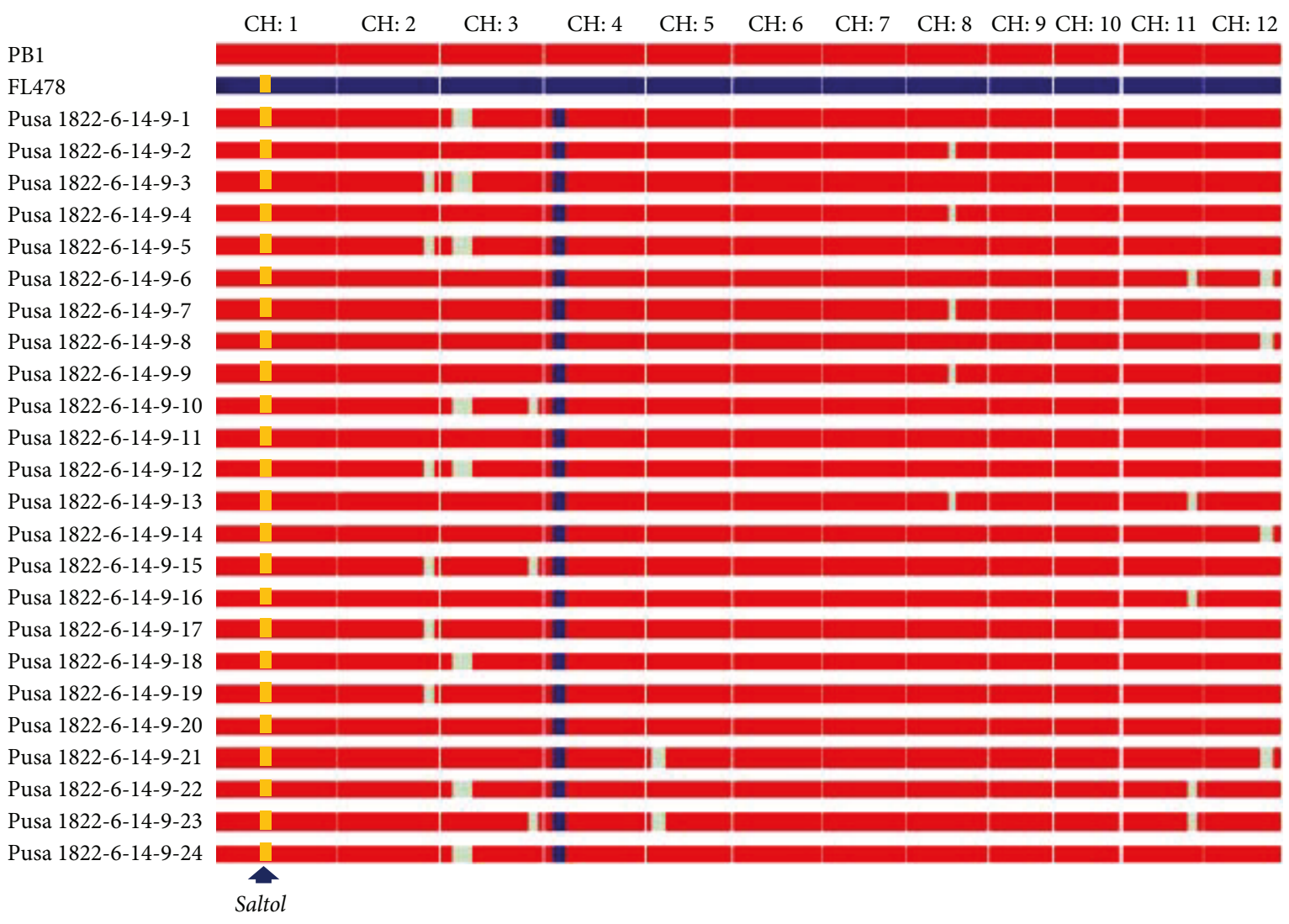

FIGURE 2: Graphical representation of the genotypes of 24 Saltol-introgressed NILs of PB1. The recurrent parent genome recovery ranged between 96.0 and $98.4 \%$. All the NILs had maximum recovery on the carrier chromosome 1. $\mathrm{CH}$ : chromosome.

markers. These six $B C_{1} F_{1}$ plants were phenotypically closer to PB1 than the other plants. Background analysis of these six plants using the 62 SSR markers indicated an average RPG recovery of $75.3 \%$ (range, 72.6 to $79.8 \%$ ). One progeny with the highest RPG recovery (79.8\%), Pusa 1822-6, was backcrossed with $\mathrm{PB} 1$ to generate $70 B \mathrm{C}_{2} F_{1}$ seeds. In the $B C_{2} F_{1}$ generation, 14 plants were heterozygous for all three Saltol-linked markers; these plants were subjected to phenotypic selection to identify six plants that were phenotypically closer to PB1 for agro-morphological and grain quality traits than the remaining plants. Background analysis of these six plants, using 21 unfixed markers in Pusa 1822-6, indicated RPG recovery from $86.3 \%$ to $89.5 \%$, with an average of $87.8 \%$. All the six plants were selfed to generate six $B C_{2} F_{2}$ families. A total of $60 \mathrm{BC}_{2} F_{2}$ plants, 10 plants each from a family, were subjected to foreground selection. Eleven $B C_{2} F_{2}$ plants were found to be homozygous for the three Saltol-linked markers. Background analysis of these plants showed RPG recovery ranging from 89.9 to $92.7 \%$ with an average of $91.2 \%$. These plants were further characterised for morphological and grain quality traits. Screening of eleven $B C_{2} F_{3}$ families raised by selfing of the selected $\mathrm{BC}_{2} \mathrm{~F}_{2}$ plants for seedling stage salinity tolerance, identified one family, Pusa 1822-6-14-9, with a salt tolerance level comparable to that of FL478. All the plants of this family from the screening system were field transplanted to raise $B C_{2} F_{3}$ population.
The $\mathrm{BC}_{2} \mathrm{~F}_{3}$ plants from Pusa 1822-6-14-9 were evaluated for both agro-morphological and grain quality traits, and 24 plants were selected for closer similarity with PB1. Background analysis of these plants, using six unfixed markers in the previous generation, indicated a cumulative RPG recovery of 96.0 to $98.4 \%$ (Table 2). All the 24 plants were advanced to $B C_{2} F_{4}$ generation by selfing. No selection was done beyond $B C_{2} F_{4}$ as all the Saltol-introgressed PB1 NILs had an average RPG recovery of more than $97 \%$. Some residual donor segments were observed in chromosomes 2, 3, 5, 8, 11 , and 12 , whereas complete recovery was achieved in chromosomes 1, 6, 7, 9, and 10 (Figure 2). These lines are sequentially identified as NIL1 (Pusa 1822-6-14-9-1) to NIL24 (Pusa 1822-6-14-9-24).

3.3. Seedling Stage Salinity Tolerance. All the 24 NILs showed good seedling stage salinity tolerance (score of 1 ) comparable to that of FL478 under a salt stress of $11.6 \mathrm{dSm}^{-1}(100 \mathrm{mM}$ of $\mathrm{NaCl})$ for sixteen days. In contrast, $\mathrm{PB} 1$ showed a highly sensitive reaction (score of 9) (Table 2; Supplementary Figure $1[\mathrm{~b}])$. The concentrations of major cations, $\mathrm{Na}^{+}$and $\mathrm{K}^{+}$, that influence the salt response in rice seedlings are presented in Table 3. Broadly, there was significant variation among the NILs and their parents for cation contents and their ratios in both shoots and roots under both stressed as well as unstressed conditions. Under unstressed conditions, the root and shoot cation contents of the parental lines were 
TABLE 3: Cation $\left(\mathrm{Na}^{+}\right.$and $\left.\mathrm{K}^{+}\right)$content in the Saltol-introgressed PB1 lines and the donor and recipient parents under salt-stressed and saltunstressed treatments.

\begin{tabular}{|c|c|c|c|c|c|c|c|c|c|c|c|c|}
\hline \multirow{3}{*}{ NILs } & \multicolumn{6}{|c|}{ Unstressed } & \multicolumn{6}{|c|}{ Salt stressed } \\
\hline & & Shoot & & & Root & & & Shoot & & & Root & \\
\hline & $\mathrm{Na}^{+}$ & $\mathrm{K}^{+}$ & $\mathrm{Na}^{+} / \mathrm{K}^{+}$ & $\mathrm{Na}^{+}$ & $\mathrm{K}^{+}$ & $\mathrm{Na}^{+} / \mathrm{K}^{+}$ & $\mathrm{Na}^{+}$ & $\mathrm{K}^{+}$ & $\mathrm{Na}^{+} / \mathrm{K}^{+}$ & $\mathrm{Na}^{+}$ & $\mathrm{K}^{+}$ & $\mathrm{Na}^{+} / \mathrm{K}^{+}$ \\
\hline NIL1 & $2.8^{\mathrm{a}-\mathrm{f} *}$ & $26.5^{\mathrm{b}-\mathrm{d}}$ & $0.11^{\mathrm{a}-\mathrm{f}}$ & $3.3^{\mathrm{ij}}$ & $27.2^{\mathrm{a}-\mathrm{c}}$ & $0.12^{\mathrm{j}}$ & $15.2^{i-1}$ & $23.6^{\mathrm{a}-\mathrm{d}}$ & $0.65^{\mathrm{b}}$ & $20.7^{\mathrm{d}-\mathrm{f}}$ & $23.9^{\mathrm{b}-\mathrm{e}}$ & $0.86^{\mathrm{e}-\mathrm{i}}$ \\
\hline NIL2 & $2.7^{\mathrm{a}-\mathrm{f}}$ & $29.0^{\mathrm{a}-\mathrm{d}}$ & $0.09^{b-f}$ & $3.6^{\mathrm{e}-\mathrm{j}}$ & $17.7^{\mathrm{k}}$ & $0.21^{\mathrm{a}-\mathrm{d}}$ & $13.8^{\mathrm{j}-1}$ & $23.2^{\mathrm{a}-\mathrm{d}}$ & $0.60^{\mathrm{b}}$ & $20.1^{\mathrm{e}-\mathrm{g}}$ & $20.8^{\mathrm{g}-\mathrm{i}}$ & $0.97^{\mathrm{c}-\mathrm{f}}$ \\
\hline NIL3 & $2.4^{\mathrm{c}-\mathrm{f}}$ & $28.9^{\mathrm{a}-\mathrm{d}}$ & $0.08^{\mathrm{c}-\mathrm{f}}$ & $5.1^{\mathrm{a}}$ & $24.1^{\mathrm{c}-\mathrm{f}}$ & $0.21^{\mathrm{a}-\mathrm{c}}$ & $12.2^{1}$ & $22.0^{\mathrm{a}-\mathrm{e}}$ & $0.56^{\mathrm{b}}$ & $19.5^{\mathrm{e}-\mathrm{h}}$ & $23.6^{\mathrm{b}-\mathrm{f}}$ & $0.82^{\mathrm{e}-\mathrm{j}}$ \\
\hline NIL4 & $3.4^{\mathrm{a}-\mathrm{e}}$ & $28.7^{\mathrm{a}-\mathrm{d}}$ & $0.12^{\mathrm{a}-\mathrm{f}}$ & $3.6^{\mathrm{f}-\mathrm{j}}$ & $18.0^{\mathrm{k}}$ & $0.2^{\mathrm{a}-\mathrm{f}}$ & $24.5^{\mathrm{b}-\mathrm{d}}$ & $21.2^{\mathrm{a}-\mathrm{e}}$ & $1.16^{\mathrm{b}}$ & $14.6^{\mathrm{m}-\mathrm{o}}$ & $15.1^{\mathrm{lm}}$ & $0.98^{\mathrm{b}-\mathrm{e}}$ \\
\hline NIL5 & $2.1^{\mathrm{ef}}$ & $32.4^{\mathrm{a}-\mathrm{d}}$ & $0.07^{\mathrm{ef}}$ & $3.7^{\mathrm{e}-\mathrm{j}}$ & $21.9^{f-i}$ & $0.17^{\mathrm{e}-\mathrm{i}}$ & $23.0^{\mathrm{c}-\mathrm{f}}$ & $25.7^{\mathrm{a}-\mathrm{c}}$ & $0.89^{\mathrm{b}}$ & $19.1^{\mathrm{e}-\mathrm{h}}$ & $26.3^{\mathrm{b}}$ & $0.73^{f-j}$ \\
\hline NIL6 & $2.5^{\mathrm{b}-\mathrm{f}}$ & $28.7^{\mathrm{a}-\mathrm{d}}$ & $0.09^{\mathrm{b}-\mathrm{f}}$ & $3.4^{\mathrm{g}-\mathrm{j}}$ & $23.2^{\mathrm{e}-\mathrm{g}}$ & $0.15^{\mathrm{ij}}$ & $22.4^{\mathrm{d}-\mathrm{f}}$ & $23.3^{\mathrm{a}-\mathrm{d}}$ & $0.96^{\mathrm{b}}$ & $19.2^{\mathrm{e}-\mathrm{h}}$ & $23.0^{\mathrm{c}-\mathrm{g}}$ & $0.83^{\mathrm{e}-\mathrm{j}}$ \\
\hline NIL7 & $3.8^{\mathrm{a}-\mathrm{e}}$ & $26.8^{\mathrm{b}-\mathrm{d}}$ & $0.14^{\mathrm{a}-\mathrm{e}}$ & $4.7^{\mathrm{a}-\mathrm{d}}$ & $27.9^{\mathrm{ab}}$ & $0.17^{\mathrm{e}-\mathrm{i}}$ & $27.0^{\mathrm{bc}}$ & $25.0^{\mathrm{a}-\mathrm{d}}$ & $1.10^{\mathrm{b}}$ & $20.9^{\text {de }}$ & $18.6^{\mathrm{i}-\mathrm{k}}$ & $1.13^{\mathrm{b}-\mathrm{d}}$ \\
\hline NIL8 & $2.7^{\mathrm{a}-\mathrm{f}}$ & $30.6^{\mathrm{a}-\mathrm{d}}$ & $0.09^{\mathrm{b}-\mathrm{f}}$ & $5.0^{\mathrm{ab}}$ & $29.0^{\mathrm{a}}$ & $0.17^{\mathrm{d}-\mathrm{i}}$ & $21.2^{\mathrm{d}-\mathrm{h}}$ & $22.5^{\mathrm{a}-\mathrm{d}}$ & $0.94^{\mathrm{b}}$ & $11.0^{\mathrm{q}}$ & $16.3^{\mathrm{k}-\mathrm{m}}$ & $0.68^{\mathrm{g}-\mathrm{j}}$ \\
\hline NIL9 & $3.5^{\mathrm{a}-\mathrm{e}}$ & $31.2^{\mathrm{a}-\mathrm{d}}$ & $0.11^{\mathrm{a}-\mathrm{f}}$ & $4.3^{\mathrm{b}-\mathrm{e}}$ & $18.2^{\mathrm{jk}}$ & $0.23^{\mathrm{a}}$ & $18.7^{\mathrm{f}-\mathrm{i}}$ & $21.6^{\mathrm{a}-\mathrm{e}}$ & $0.86^{\mathrm{b}}$ & $24.0^{\mathrm{c}}$ & $19.6^{\mathrm{h}-\mathrm{j}}$ & $1.22^{\mathrm{b}}$ \\
\hline NIL10 & $4.3^{\mathrm{a}-\mathrm{c}}$ & $25.2^{\mathrm{c}-\mathrm{e}}$ & $0.18^{\mathrm{a}}$ & $4.8^{\mathrm{a}-\mathrm{c}}$ & $27.2^{\mathrm{a}-\mathrm{c}}$ & $0.17^{\mathrm{c}-\mathrm{i}}$ & $12.4^{\mathrm{kl}}$ & $12.2^{\mathrm{e}}$ & $1.21^{\mathrm{b}}$ & $18.2^{\mathrm{g}-\mathrm{j}}$ & $20.6^{\mathrm{g}-\mathrm{i}}$ & $0.88^{\mathrm{d}-\mathrm{i}}$ \\
\hline NIL11 & $4.5^{\mathrm{ab}}$ & $30.3^{\mathrm{a}-\mathrm{d}}$ & $0.15^{\mathrm{a}-\mathrm{d}}$ & $4.1^{\mathrm{c}-\mathrm{g}}$ & $26.6^{\mathrm{a}-\mathrm{c}}$ & $0.16^{\mathrm{g}-\mathrm{j}}$ & $13.2^{\mathrm{kl}}$ & $28.1^{\mathrm{ab}}$ & $0.47^{\mathrm{b}}$ & $14.0^{\text {no }}$ & $21.1^{\mathrm{f}-\mathrm{i}}$ & $0.66^{h-j}$ \\
\hline NIL12 & $2.4^{\mathrm{c}-\mathrm{f}}$ & $31.1^{\mathrm{a}-\mathrm{d}}$ & $0.08^{\mathrm{d}-\mathrm{f}}$ & $3.3^{\mathrm{h}-\mathrm{j}}$ & $19.0^{\mathrm{i}-\mathrm{k}}$ & $0.18^{\mathrm{c}-\mathrm{i}}$ & $13.9^{\mathrm{j}-1}$ & $17.9^{\mathrm{c}-\mathrm{e}}$ & $0.78^{\mathrm{b}}$ & $11.3^{\mathrm{pq}}$ & $15.3^{\operatorname{lm}}$ & $0.74^{e-j}$ \\
\hline NIL13 & $2.6^{b-f}$ & $17.7^{\mathrm{e}}$ & $0.15^{\mathrm{a}-\mathrm{d}}$ & $4.7^{\mathrm{a}-\mathrm{d}}$ & $25.3^{\mathrm{b}-\mathrm{e}}$ & $0.19^{\mathrm{b}-\mathrm{h}}$ & $16.2^{\mathrm{i}-1}$ & $21.3^{\mathrm{a}-\mathrm{e}}$ & $0.76^{\mathrm{b}}$ & $11.3^{\mathrm{pq}}$ & $16.7^{\mathrm{k}-\mathrm{m}}$ & $0.68^{g-j}$ \\
\hline NIL14 & $2.6^{b-f}$ & $26.7^{\mathrm{b}-\mathrm{d}}$ & $0.10^{\mathrm{b}-\mathrm{f}}$ & $4.0^{\mathrm{d}-\mathrm{h}}$ & $21.4^{\mathrm{f}-\mathrm{i}}$ & $0.19^{\mathrm{b}-\mathrm{h}}$ & $25.6^{\mathrm{b}-\mathrm{d}}$ & $24.7^{\mathrm{a}-\mathrm{d}}$ & $1.05^{\mathrm{b}}$ & $13.4^{\mathrm{op}}$ & $14.5^{\mathrm{m}}$ & $0.92^{\mathrm{d}-\mathrm{g}}$ \\
\hline NIL15 & $2.8^{\mathrm{a}-\mathrm{f}}$ & $27.0^{\mathrm{b}-\mathrm{d}}$ & $0.11^{\mathrm{a}-\mathrm{f}}$ & $5.1^{\mathrm{a}}$ & $21.9^{\mathrm{f}-\mathrm{i}}$ & $0.23^{\mathrm{a}}$ & $27.1^{b c}$ & $24.6^{\mathrm{a}-\mathrm{d}}$ & $1.15^{\mathrm{b}}$ & $26.7^{\mathrm{b}}$ & $22.6^{\mathrm{d}-\mathrm{g}}$ & $1.18^{\mathrm{bc}}$ \\
\hline NIL16 & $4.1^{\mathrm{a}-\mathrm{e}}$ & $28.5^{\mathrm{a}-\mathrm{d}}$ & $0.14^{\mathrm{a}-\mathrm{e}}$ & $3.0^{j}$ & $19.6^{\mathrm{h}-\mathrm{k}}$ & $0.16^{\mathrm{g}-\mathrm{j}}$ & $17.7^{g-j}$ & $15.5^{\mathrm{de}}$ & $1.22^{\mathrm{b}}$ & $13.8^{\text {no }}$ & $20.6^{\mathrm{g}-\mathrm{i}}$ & $0.67^{h-j}$ \\
\hline NIL17 & $3.1^{\mathrm{a}-\mathrm{f}}$ & $34.9^{\mathrm{a}}$ & $0.09^{\mathrm{b}-\mathrm{f}}$ & $4.2^{\mathrm{c}-\mathrm{f}}$ & $22.9^{\mathrm{e}-\mathrm{g}}$ & $0.18^{\mathrm{b}-\mathrm{i}}$ & $21.5^{\mathrm{d}-\mathrm{g}}$ & $24.8^{\mathrm{a}-\mathrm{d}}$ & $0.87^{\mathrm{b}}$ & $16.2^{\mathrm{j}-\mathrm{m}}$ & $22.9^{\mathrm{d}-\mathrm{g}}$ & $0.71^{\mathrm{g}-\mathrm{j}}$ \\
\hline NIL18 & $2.9^{\mathrm{a}-\mathrm{f}}$ & $32.9^{\mathrm{a}-\mathrm{c}}$ & $0.09^{\mathrm{b}-\mathrm{f}}$ & $4.2^{\mathrm{c}-\mathrm{f}}$ & $21.2^{\mathrm{f}-\mathrm{j}}$ & $0.2^{\mathrm{a}-\mathrm{e}}$ & $23.5^{\mathrm{b}-\mathrm{e}}$ & $22.9^{\mathrm{a}-\mathrm{d}}$ & $1.03^{\mathrm{b}}$ & $18.7^{\mathrm{f}-\mathrm{i}}$ & $21.8^{\mathrm{e}-\mathrm{h}}$ & $0.86^{\mathrm{e}-\mathrm{i}}$ \\
\hline NIL19 & $4.4^{\mathrm{ab}}$ & $32.0^{\mathrm{a}-\mathrm{d}}$ & $0.14^{\mathrm{a}-\mathrm{e}}$ & $4.2^{\mathrm{c}-\mathrm{f}}$ & $19.6^{\mathrm{h}-\mathrm{k}}$ & $0.22^{\mathrm{ab}}$ & $24.9^{\mathrm{b}-\mathrm{d}}$ & $24.7^{\mathrm{a}-\mathrm{d}}$ & $1.01^{\mathrm{b}}$ & $15.9^{\mathrm{k}-\mathrm{n}}$ & $24.9^{\mathrm{b}-\mathrm{d}}$ & $0.64^{\mathrm{ij}}$ \\
\hline NIL20 & $1.3^{\mathrm{f}}$ & $31.8^{\mathrm{a}-\mathrm{d}}$ & $0.04^{\mathrm{f}}$ & $5.1^{\mathrm{a}}$ & $26.8^{\mathrm{a}-\mathrm{c}}$ & $0.19^{\mathrm{b}-\mathrm{g}}$ & $16.9^{\mathrm{h}-\mathrm{k}}$ & $18.1^{\mathrm{c}-\mathrm{e}}$ & $0.94^{\mathrm{b}}$ & $13.6^{\circ}$ & $17.5^{\mathrm{j}-1}$ & $0.78^{\mathrm{e}-\mathrm{j}}$ \\
\hline NIL21 & $2.2^{\mathrm{d}-\mathrm{f}}$ & $33.8^{\mathrm{ab}}$ & $0.07^{\mathrm{ef}}$ & $3.9^{\mathrm{e}-\mathrm{i}}$ & $18.9^{\mathrm{i}-\mathrm{k}}$ & $0.20^{\mathrm{a}-\mathrm{e}}$ & $22.6^{\mathrm{c}-\mathrm{f}}$ & $22.7^{\mathrm{a}-\mathrm{d}}$ & $0.99^{\mathrm{b}}$ & $19.1^{\mathrm{e}-\mathrm{h}}$ & $21.2^{\mathrm{f}-\mathrm{i}}$ & $0.90^{\mathrm{d}-\mathrm{h}}$ \\
\hline NIL22 & $4.1^{\mathrm{a}-\mathrm{d}}$ & $24.9^{\mathrm{de}}$ & $0.17^{\mathrm{ab}}$ & $4.2^{\mathrm{c}-\mathrm{f}}$ & $23.4^{\mathrm{d}-\mathrm{f}}$ & $0.18^{\mathrm{c}-\mathrm{i}}$ & $22.1^{\mathrm{d}-\mathrm{g}}$ & $18.6^{\mathrm{b}-\mathrm{e}}$ & $1.20^{\mathrm{b}}$ & $17.0^{\mathrm{i}-1}$ & $19.8^{\mathrm{h}-\mathrm{j}}$ & $0.86^{\mathrm{e}-\mathrm{i}}$ \\
\hline NIL23 & $4.6^{\mathrm{a}}$ & $29.0^{\mathrm{a}-\mathrm{d}}$ & $0.16^{\mathrm{a}-\mathrm{c}}$ & $4.1^{\mathrm{c}-\mathrm{g}}$ & $26.5^{\mathrm{a}-\mathrm{d}}$ & $0.15^{\mathrm{h}-\mathrm{j}}$ & $22.9^{\mathrm{c}-\mathrm{f}}$ & $26.9^{\mathrm{a}-\mathrm{c}}$ & $0.85^{\mathrm{b}}$ & $15.4^{1-\mathrm{o}}$ & $25.6^{\mathrm{bc}}$ & $0.60^{\mathrm{j}}$ \\
\hline NIL24 & $4.3^{\mathrm{a}-\mathrm{c}}$ & $32.8^{\mathrm{a}-\mathrm{c}}$ & $0.13^{\mathrm{a}-\mathrm{e}}$ & $3.5^{\mathrm{g}-\mathrm{j}}$ & $21.3^{\mathrm{f}-\mathrm{j}}$ & $0.16^{\mathrm{f}-\mathrm{i}}$ & $19.4^{\mathrm{e}-\mathrm{i}}$ & $23.4^{\mathrm{a}-\mathrm{d}}$ & $0.83^{\mathrm{b}}$ & $17.8^{\mathrm{h}-\mathrm{k}}$ & $20.4^{\mathrm{g}-\mathrm{i}}$ & $0.87^{\mathrm{e}-\mathrm{i}}$ \\
\hline PB1 & $3.2^{\mathrm{a}-\mathrm{f}}$ & $25.5^{\mathrm{cd}}$ & $0.13^{\mathrm{a}-\mathrm{e}}$ & $3.8^{\mathrm{e}-\mathrm{i}}$ & $20.1^{\mathrm{g}-\mathrm{k}}$ & $0.19^{\mathrm{b}-\mathrm{h}}$ & $34.4^{\mathrm{a}}$ & $12.2^{\mathrm{e}}$ & $2.83^{\mathrm{a}}$ & $22.3^{\mathrm{cd}}$ & $8.2^{\mathrm{n}}$ & $2.72^{\mathrm{a}}$ \\
\hline FL478 & $3.6^{\mathrm{a}-\mathrm{e}}$ & $28.6^{\mathrm{a}-\mathrm{d}}$ & $0.13^{\mathrm{a}-\mathrm{e}}$ & $5.2^{\mathrm{a}}$ & $22.3^{\mathrm{e}-\mathrm{h}}$ & $0.23^{\mathrm{a}}$ & $27.9^{\mathrm{b}}$ & $29.4^{\mathrm{a}}$ & $0.95^{\mathrm{b}}$ & $29.3^{\mathrm{a}}$ & $30.4^{\mathrm{a}}$ & $0.96^{\mathrm{c}-\mathrm{f}}$ \\
\hline CV (\%) & 15.25 & 6.48 & 17.33 & 4.12 & 3.33 & 4.82 & 5.30 & 10.84 & 19.34 & 2.88 & 3.17 & 6.57 \\
\hline SE & 0.49 & 1.88 & 0.02 & 0.17 & 0.76 & 0.01 & 1.10 & 2.40 & 0.19 & 0.51 & 0.65 & 0.06 \\
\hline
\end{tabular}

${ }^{*}$ Means followed by the same letter are statistically not different at $p<0.05$, by Tukey's honest significance test. CV: coefficient of variation; SE: standard error.

TABLE 4: Interrelationships of cation content and their proportions in root and shoots under unstressed (lower diagonal) and salt-stressed (upper diagonal) conditions. Cross correlations between unstressed and stressed conditions are given as diagonal elements.

\begin{tabular}{|c|c|c|c|c|c|c|c|}
\hline Parameters $^{\dagger}$ & St: $\mathrm{Na}^{+}$ & St: $\mathrm{K}^{+}$ & St: $\mathrm{Na}^{+} / \mathrm{K}^{+}$ & Rt: $\mathrm{Na}^{+}$ & Rt: $\mathrm{K}^{+}$ & Rt: $\mathrm{Na}^{+} / \mathrm{K}^{+}$ & STS \\
\hline St: $\mathrm{Na}^{+}$ & 0.072 & 0.101 & $0.658^{*}$ & $0.380^{*}$ & -0.130 & $0.545^{*}$ & $0.494^{*}$ \\
\hline St: $\mathrm{K}^{+}$ & -0.063 & 0.171 & $-0.625^{*}$ & 0.186 & $0.567^{*}$ & $-0.389^{*}$ & $-0.437^{*}$ \\
\hline St: $\mathrm{Na}^{+} / \mathrm{K}^{+}$ & $0.864^{*}$ & $-0.534^{*}$ & 0.107 & 0.197 & $-0.519^{*}$ & $0.801^{*}$ & $0.833^{*}$ \\
\hline $\mathrm{Rt}: \mathrm{Na}^{+}$ & -0.105 & -0.161 & 0.013 & 0.227 & $0.405^{*}$ & $0.465^{*}$ & 0.201 \\
\hline Rt: $\mathrm{K}^{+}$ & 0.052 & -0.250 & 0.176 & $0.480^{*}$ & 0.115 & $-0.537^{*}$ & $-0.551^{*}$ \\
\hline Rt: $\mathrm{Na}^{+} / \mathrm{K}^{+}$ & -0.135 & 0.086 & -0.148 & $0.521^{*}$ & $-0.490^{*}$ & 0.244 & $0.908^{*}$ \\
\hline
\end{tabular}

${ }^{\dagger}$ St: Shoot; Rt: Root; ${ }^{*}$ Correlation coefficients are significant at $p<0.01$ level; STS: salt tolerance score.

comparable, but there were significant differences between some NILs, and some of them differed significantly from the parents as well. However, under stressed conditions, PB1 and FL478 had significantly distinct cation concentration both in shoots and roots; while the $\mathrm{K}^{+}$levels in the shoots and roots of FL478 were much higher than those in $\mathrm{PB} 1$, the $\mathrm{Na}^{+}$content in the shoots of FL478 was significantly lower than PB1, whereas $\mathrm{Na}^{+}$content in the roots of PB1 was lower than FL478. All the NILs showed shoot and root $\mathrm{K}^{+}$ levels closer to those of FL478 than to PB1. The root $\mathrm{Na}^{+}$ 
concentration of NILs were closer to that of PB1, but shoot $\mathrm{Na}^{+}$content was comparable or marginally lower than that of FL478. Further, there were several NILs that showed $\mathrm{Na}^{+} / \mathrm{K}^{+}$ratio lower than that of FL478.

The correlations between cation content in shoots and roots (Table 4) under stressed and nonstressed conditions were insignificant. Under salt stress, salt tolerance score was found to have a significant positive association with shoot $\mathrm{Na}^{+}$content, while shoot $\mathrm{K}^{+}$level showed a negative association. Similar trend was observed for root ion concentrations under stress, except for root $\mathrm{Na}^{+}$content, which exhibited nonsignificant correlation. The ionic proportions had shown very high negative association with salt tolerance score in both shoots and roots.

Correlations among the cation contents in shoots and roots under salt stress, indicated several significant associations such as a positive trend between shoot $\mathrm{Na}^{+}$content and root $\mathrm{Na}^{+}$content $(0.38)$, as well as between shoot $\mathrm{K}^{+}$ and root $\mathrm{K}^{+}$contents $(0.57)$. There were no associations between shoot $\mathrm{Na}^{+}$and root $\mathrm{K}^{+}$levels and vice versa. $\mathrm{Na}^{+}$ content showed a major positive association with $\mathrm{Na}^{+} / \mathrm{K}^{+}$ ratio in both shoots and roots (0.66 and 0.47 , resp.), while the $\mathrm{K}^{+}$content showed significant negative association with the $\mathrm{Na}^{+} / \mathrm{K}^{+}$ratio $(-0.63$ and -0.54 , resp.). The cation ratios between shoots and roots also showed a positive trend (0.80). Further, cross associations were also noticed for shoot ion concentrations with root cation ratios $(0.55$ and -0.39 , resp., for shoot $\mathrm{Na}^{+}$and $\mathrm{K}^{+}$contents), while root $\mathrm{K}^{+}$showed a negative association with shoot $\mathrm{Na}^{+} / \mathrm{K}^{+}$ratio $(-0.52)$, but no such association was found with root $\mathrm{Na}^{+}$ content. Further, root $\mathrm{Na}^{+}$and $\mathrm{K}^{+}$contents showed a positive association (0.41).

3.4. Agronomic Performance. Mean performance of each of the 24 PB1 NILs for yield and yield-related traits is presented in Table 2. The NILs were essentially comparable to the recurrent parent, $\mathrm{PB} 1$, for agronomic traits, such as plant height, panicle length, weight of 1000 grains, and yield per plant. The days to $50 \%$ flowering ranged from 95.0 days (NIL19) to 106 days (NIL4, 6, 7, and 22): 23 NILs were at par with PB1 (103 days), while NIL19 was significantly flowering earlier than PB1.

3.5. Grain and Cooking Quality. The mean grain and cooking quality parameters of the NILs are presented in Table 5. Hulling and milling percentages for all the NILs were similar to those of the recurrent parent, PB1. Further, all the NILs possessed extra-long slender grain type (Figure 3) with strong aroma and with low gelatinization temperature as indicated by the alkali spreading value of 7.0, which is the same as that of PB1. Some of the NILs had significantly longer grain length before/after cooking than the RP while few had them significantly shorter, but these differences were rather small $(0.15 \mathrm{~mm}$ or less).

\section{Discussion}

Growing demand for Basmati rice has resulted in its increased cultivation in the north-western areas of India
TABLE 5: Grain and cooking quality of Saltol-introgressed NILs of Pusa Basmati 1 (Pusa 1822).

\begin{tabular}{|c|c|c|c|c|c|c|c|}
\hline NILS & HUL & MIL & KLBC & KLAC & ER & ASV & AROM \\
\hline NIL1 & $75.5^{\mathrm{a}}$ & $66.9^{\mathrm{a}}$ & $7.29^{\mathrm{a}}$ & $13.32^{\mathrm{a}}$ & $1.822^{\mathrm{de}}$ & 7.0 & 2.0 \\
\hline NIL2 & $73.7^{\mathrm{a}}$ & $65.3^{\mathrm{a}}$ & $7.21^{\mathrm{d}-\mathrm{g}}$ & $13.21^{\mathrm{b}-\mathrm{d}}$ & $1.832^{\mathrm{c}-\mathrm{e}}$ & 7.0 & 2.0 \\
\hline NIL3 & $74.7^{\mathrm{a}}$ & $68.7^{\mathrm{a}}$ & $7.27^{\mathrm{a}-\mathrm{c}}$ & $13.24^{\mathrm{bc}}$ & $1.819^{\mathrm{ef}}$ & 7.0 & 2.0 \\
\hline NIL4 & $72.8^{\mathrm{a}}$ & $64.7^{\mathrm{a}}$ & $7.20^{\mathrm{e}-\mathrm{h}}$ & $13.21^{\mathrm{b}-\mathrm{d}}$ & $1.837^{\mathrm{a}-\mathrm{c}}$ & 7.0 & 2.0 \\
\hline NIL5 & $72.7^{\mathrm{a}}$ & $64.6^{\mathrm{a}}$ & $7.22^{\mathrm{d}-\mathrm{f}}$ & $13.21^{\mathrm{b}-\mathrm{d}}$ & $1.825^{\mathrm{de}}$ & 7.0 & 2.0 \\
\hline NIL6 & $74.8^{\mathrm{a}}$ & $66.0^{\mathrm{a}}$ & $7.19^{\mathrm{f}-\mathrm{i}}$ & $13.12^{\mathrm{fg}}$ & $1.822^{\mathrm{de}}$ & 7.0 & 2.0 \\
\hline NIL7 & $69.7^{\mathrm{a}}$ & $62.9^{\mathrm{a}}$ & $7.23^{c-f}$ & $13.20^{\mathrm{cd}}$ & $1.827^{\mathrm{c}-\mathrm{e}}$ & 7.0 & 2.0 \\
\hline NIL8 & $74.0^{\mathrm{a}}$ & $66.7^{\mathrm{a}}$ & $7.29^{\mathrm{ab}}$ & $13.26^{\mathrm{b}}$ & $1.819^{\mathrm{ef}}$ & 7.0 & 2.0 \\
\hline NIL9 & $74.2^{\mathrm{a}}$ & $66.5^{\mathrm{a}}$ & $7.25^{\mathrm{b}-\mathrm{d}}$ & $13.22^{\mathrm{bc}}$ & $1.822^{\mathrm{de}}$ & 7.0 & 2.0 \\
\hline NIL10 & $73.5^{\mathrm{a}}$ & $66.5^{\mathrm{a}}$ & $7.19^{\mathrm{f}-\mathrm{i}}$ & $13.20^{\mathrm{cd}}$ & $1.836^{\mathrm{a}-\mathrm{c}}$ & 7.0 & 2.0 \\
\hline NIL11 & $75.6^{\mathrm{a}}$ & $67.5^{\mathrm{a}}$ & $7.29^{\mathrm{ab}}$ & $13.31^{\mathrm{a}}$ & $1.826^{\mathrm{c}-\mathrm{e}}$ & 7.0 & 2.0 \\
\hline NIL12 & $74.7^{\mathrm{a}}$ & $66.2^{\mathrm{a}}$ & $7.28^{\mathrm{ab}}$ & $13.07^{\mathrm{g}}$ & $1.795^{\mathrm{g}}$ & 7.0 & 2.0 \\
\hline NIL13 & $73.4^{\mathrm{a}}$ & $65.7^{\mathrm{a}}$ & $7.21^{\mathrm{d}-\mathrm{g}}$ & $13.21^{\mathrm{b}-\mathrm{d}}$ & $1.830^{\mathrm{c}-\mathrm{e}}$ & 7.0 & 2.0 \\
\hline NIL14 & $76.4^{\mathrm{a}}$ & $67.9^{\mathrm{a}}$ & $7.20^{\mathrm{e}-\mathrm{h}}$ & $13.19^{\mathrm{cd}}$ & $1.832^{\mathrm{c}-\mathrm{e}}$ & 7.0 & 2.0 \\
\hline NIL15 & $73.7^{\mathrm{a}}$ & $65.6^{\mathrm{a}}$ & $7.16^{\mathrm{hi}}$ & $13.15^{\mathrm{ef}}$ & $1.837^{\mathrm{b}-\mathrm{d}}$ & 7.0 & 2.0 \\
\hline NIL16 & $73.5^{\mathrm{a}}$ & $67.6^{\mathrm{a}}$ & $7.27^{\mathrm{a}-\mathrm{c}}$ & $13.25^{\mathrm{bc}}$ & $1.823^{\mathrm{ef}}$ & 7.0 & 2.0 \\
\hline NIL17 & $73.5^{\mathrm{a}}$ & $67.7^{\mathrm{a}}$ & $7.24^{\mathrm{c}-\mathrm{e}}$ & $13.00^{\mathrm{h}}$ & $1.796^{\mathrm{g}}$ & 7.0 & 2.0 \\
\hline NIL18 & $74.2^{\mathrm{a}}$ & $66.9^{\mathrm{a}}$ & $7.17^{\mathrm{g}-\mathrm{i}}$ & $13.23^{\mathrm{bc}}$ & $1.845^{\mathrm{a}}$ & 7.0 & 2.0 \\
\hline NIL19 & $76.5^{\mathrm{a}}$ & $68.7^{\mathrm{a}}$ & $7.22^{\mathrm{d}-\mathrm{f}}$ & $13.21^{\mathrm{b}-\mathrm{d}}$ & $1.835^{\mathrm{c}-\mathrm{e}}$ & 7.0 & 2.0 \\
\hline NIL20 & $73.6^{\mathrm{a}}$ & $66.5^{\mathrm{a}}$ & $7.21^{\mathrm{d}-\mathrm{g}}$ & $13.18^{\mathrm{de}}$ & $1.828^{\mathrm{c}-\mathrm{e}}$ & 7.0 & 2.0 \\
\hline NIL21 & $73.4^{\mathrm{a}}$ & $65.6^{\mathrm{a}}$ & $7.20^{\mathrm{e}-\mathrm{h}}$ & $13.21^{\mathrm{b}-\mathrm{d}}$ & $1.837^{\mathrm{a}-\mathrm{c}}$ & 7.0 & 2.0 \\
\hline NIL22 & $71.9^{\mathrm{a}}$ & $64.9^{\mathrm{a}}$ & $7.20^{\mathrm{e}-\mathrm{h}}$ & $13.20^{\mathrm{cd}}$ & $1.835^{\mathrm{c}-\mathrm{e}}$ & 7.0 & 2.0 \\
\hline NIL23 & $74.3^{\mathrm{a}}$ & $65.1^{\mathrm{a}}$ & $7.15^{\mathrm{i}}$ & $13.20^{\mathrm{cd}}$ & $1.846^{\mathrm{a}}$ & 7.0 & 2.0 \\
\hline NIL24 & $73.4^{\mathrm{a}}$ & $71.6^{\mathrm{a}}$ & $7.15^{\mathrm{i}}$ & $13.20^{\mathrm{cd}}$ & $1.844^{\mathrm{ab}}$ & 7.0 & 2.0 \\
\hline PB1 & $73.9^{\mathrm{a}}$ & $66.0^{\mathrm{a}}$ & $7.30^{\mathrm{a}}$ & $13.21^{\mathrm{b}-\mathrm{d}}$ & $1.810^{\mathrm{fg}}$ & 7.0 & 2.0 \\
\hline FL478 & 79.1 & 64.4 & 6.28 & 9.13 & 1.454 & 5.0 & 0.0 \\
\hline CV (\%) & 2.14 & 3.60 & 0.14 & 0.09 & 0.18 & - & - \\
\hline SE & 1.58 & 2.39 & 0.01 & 0.01 & 0.00 & - & - \\
\hline
\end{tabular}

Means followed by same letters are statistically not different at $p<0.05$, by Tukey's honest significance test. HUL: hulling recovery in percentage; MIL: milling recovery in percentage; KLBC: kernel length before cooking in $\mathrm{mm}$; KLAC: kernel length after cooking in mm; ASV: alkali spreading value; AROM: aroma score from panel test; $\mathrm{CV}$ : coefficient of variation; $\mathrm{SE}$ : standard error.

$[11,12]$. However, soil salinization in these regions poses a major threat to cropping as salinity stress leads to poor crop establishment and survival resulting in significant yield losses. Therefore, it is important to develop salt stress tolerant Basmati cultivars for cultivation in these areas [37]. In the present study, marker-assisted backcross breeding based on the established step-wise selection approach, namely, foreground, phenotypic, and background selections in the given order, was successful in improving the salt tolerance of PB1 Basmati rice variety. Stringent phenotypic selection carried out after the foreground selection is reported to accelerate RP genome recovery process $[5,11,38,39]$ and is expected to reduce the cost of background selection by reducing the number of test plants. It is noteworthy that very high ( $96-98 \%)$ RPG recovery was achieved with only two backcrosses, and the recovery of the Basmati grain and cooking 


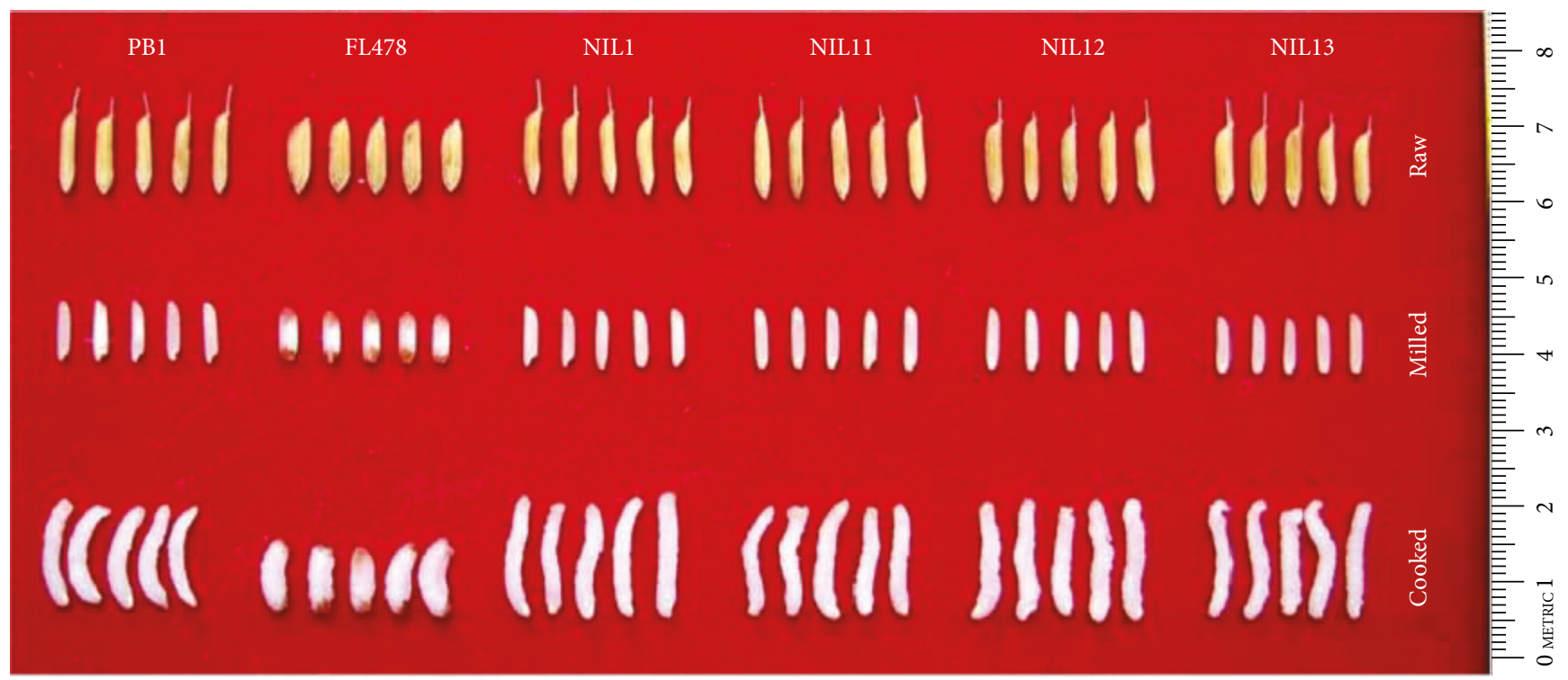

FIgURE 3: Grain and cooking quality of some of the NILs of Pusa Basmati 1 carrying Saltol locus.

quality traits was almost complete. Further, there was complete recovery of the carrier chromosome (chromosome 1) together with Saltol, the target QTL (Figure 2; Supplementary Figure 1; Supplementary Table 1); this might have been facilitated by the relatively low level of polymorphism (11.1\%) for this chromosome. This indicates the effectiveness of the selection procedure used in the study.

It is pertinent here to mention that $\mathrm{PB} 1$ was reported to possess a Saltol haplotype that was different from other Basmati cultivars. The PB1 haplotype shared a close homology with the Saltol locus of FL478, by differing only for three markers RM8094, RM493, and RM10793 [37]. Among these, RM8094 was the only recognised Saltollinked marker that has been used for marker-assisted breeding, while RM493 and RM10793 were centromeric distal markers [20]. This implied that PB1 Saltol locus was very similar to FL478 locus, except for the region proximal to RM8094 marker locus. Therefore, the contrasting salt stress response between PB1 and FL478 can be arbitrarily assigned to a segment within 10.8 to $11.4 \mathrm{Mbp}$ on chromosome 1 . The NILs showed seedling stage salt tolerance levels comparable to that of FL478. Although, there was up to $4 \%$ residual donor genome present in some of the NILs, there was little effect of the donor genome on the agronomic performance, except for days to $50 \%$ flowering that was significantly lower than PB1 in one of the NILs, Pusa 1822-6-14-9-19.

Inspite of huge strides made in genomics-assisted breeding, development of salt-tolerant rice cultivars continues to be a major challenge due to the complex nature of Saltol region. Although, all the selected eleven $B C_{2} F_{2}$ genotypes possessed the target marker alleles in homozygous condition, they exhibited differential tolerance response ranging from susceptibility to complete tolerant at $11.6 \mathrm{dSm}^{-1}$ ECE level (Supplementary Table 3). The sensitive response of some $\mathrm{BC}_{2} \mathrm{~F}_{2}$ lines suggests the possibility that some genomic regions of PB1 may harbour genes/QTLs that have inhibitory effect on the Saltol QTL. Another possibility is cryptic intraSaltol QTL recombination that could not be detected by the three markers used for the foreground selection. It is emphasised that Saltol region is fairly large (having a size of $\sim 1.5 \mathrm{Mbp}$ ) enough to accede intra-QTL recombination, as evident from its highly fragmented existence in the rice genome [40]. Further, introgression of additional hitherto unidentified QTLs from donor into the salt tolerant NILs cannot be ruled out.

The Saltol QTL region consists of several genes associated with salt response. These include transcription factors, signal transduction components, cell wall components, and membrane transporters $[41,42]$. Specific genes, such as $\mathrm{Na}^{+}$transporter gene OsHKT1;5 [20,43], osmoprotection-associated SalT [44], cation-proton exchanger (OsCHX11), cyclic nucleotide-gated ion channel (OsCNGC1) [45], high affinity potassium transporter ( $H K T 1)$, and ATP-binding cassette transporter $(A B C 1)[42,46]$, have been recognized in this region. However, since Saltol QTL is associated with $\mathrm{Na}^{+}$/ $\mathrm{K}^{+}$balance in the shoot tissues, the implicit mechanism of tolerance is attributed to $\mathrm{Na}^{+} / \mathrm{K}^{+}$homeostasis driven by OsHKT1;5. The OsHKT1;5 gene, also known as SKC1, encodes for a xylem-expressed $\mathrm{Na}^{+}$transporter and acts by preferentially unloading $\mathrm{Na}^{+}$ions from xylem vessels while regulating $\mathrm{K}^{+}$homeostasis [19]. Current observation of absence of any relation between the cation content between stressed and unstressed conditions indicated that ion homeostasis mechanisms might be active only under salt stress. Further, under stress, the shoot cation content outweighed root cation status in determining the salt tolerance, among which $\mathrm{Na}^{+}$content was more deterministic of the level of tolerance than the $\mathrm{K}^{+}$content. This strongly suggested $\mathrm{Na}^{+}$transport as the major mechanism of salt tolerance in Saltol. The shift in $\mathrm{Na}^{+} / \mathrm{K}^{+}$cation balance in shoot tissues of NILs towards the ratio in the donor parent FL478 tends to support this suggestion. Successful recovery of Basmati grain and cooking quality traits, 
together with pleasing aroma, were achieved in this study, as in several previous studies $[1,3,4,11,39]$, in spite of the donor parent having poor grain and cooking quality traits. This was possible solely due to the marker-assisted selection strategy that combined a rigorous phenotypic selection in every generation.

\section{Conclusions}

In the present investigation, incorporation of seedling stage salinity tolerance in PB1 was achieved by introgression of the Saltol QTL using marker-assisted backcross breeding. The improved lines showed marked enhancement of salt tolerance in seedling stage. Since salt tolerance in Basmati cultivars is absent, the newly developed lines together with Saltol-introgressed NILs of Pusa Basmati 1121, another premium Basmati cultivar [11], will now offer choice of cultivars to be grown in salt-affected soils. Two of the improved NILs, Pusa 1822-6-14-9-11 and Pusa 1822-6-14-9-20 (Figure 3; Supplementary Figure 1 [c]), may be evaluated for their suitability for commercial cultivation and/or in breeding programmes for improving their reproductive stage salt tolerance, since the genetic controls of seedling and reproductive stage salt tolerance are different [47]. Additionally, a comprehensive evaluation of the NILs under salt-affected soil will reveal, other than agronomic performance, physiological improvements such as photosynthetic efficiency gained by incorporation of salt tolerance.

\section{Conflicts of Interest}

The authors declare that they have no competing interests.

\section{Authors' Contributions}

Ashok Kumar Singh conceptualised the project; Ashok Kumar Singh, Subbaiyan Gopala Krishnan, and Brahma Deo Singh led the experiment and did the evaluation and midcourse corrections; Vivek Kumar Singh, Amit Kumar, Ranjith Kumar Ellur, Subbaiyan Gopala Krishnan, and Prolay Kumar Bhowmick designed and conducted the field and phytotron experiments; Sadhna Maurya, Madan Pal Singh, and Vivek Kumar Singh did the physiological and biochemical evaluation; Vivek Kumar Singh, Kunnummal Kurungara Vinod, and Subbaiyan Gopala Krishnan did the data curation and analyses; Vivek Kumar Singh, Kunnummal Kurungara Vinod, Subbaiyan Gopala Krishnan, Brahma Deo Singh, and Ashok Kumar Singh wrote the paper. All the authors have read and approved the final manuscript.

\section{Acknowledgments}

The senior author acknowledges the help rendered by the technical and supporting staff of the rice section, Division of Genetics, for field work and Division of Soil Science, ICAR-IARI, for biochemical analysis of samples.

\section{Supplementary Materials}

Supplementary Table 1: chromosome wise list of polymorphic STMS markers between PB1 and FL478. Supplementary Table 2: information on Saltol-linked SSR markers on chromosome1 polymorphic between PB1 and FL478. Supplementary Table 3: agronomic performance, salt tolerance, and recurrent parent genome recovery of Saltol-positive homozygous $B_{2} F_{2}$ plants. Supplementary Figure 1: phenotypic evaluation for salt tolerance between parents and introgressed lines with their field view. Supplementary Figure 2: screening of foreground markers in the parental lines. Three markers RM8094, RM493, and RM10793 showed polymorphism between PB1 and FL478. (Supplementary Materials)

\section{References}

[1] K. K. Vinod, S. G. Krishnan, N. N. Babu, M. Nagarajan, and A. K. Singh, "Improving salt tolerance in rice: looking beyond the conventional," in Salt Stress in Plants: Signalling, Omics and Adaptations, P. Ahmad, M. M. Azooz and M. N. V. Prasad, Eds., pp. 219-260, Springer, New York, 2013.

[2] F. Moradi and A. M. Ismail, "Responses of photosynthesis, chlorophyll fluorescence and ROS-scavenging systems to salt stress during seedling and reproductive stages in rice," Annals of Botany, vol. 99, no. 6, pp. 1161-1173, 2007.

[3] T. M. L. Hoang, T. T. Tran, T. K. T. Nguyen et al., "Improvement of salinity stress tolerance in rice: challenges and opportunities," Agronomy, vol. 6, no. 4, p. 54, 2016.

[4] A. R. Yeo and T. J. Flowers, "Salinity resistance in rice (Oryza sativa L.) and a pyramiding approach to breeding varieties for saline soils," Australian Journal of Plant Physiology, vol. 13, no. 1, pp. 161-174, 1986.

[5] A. M. Ismail, S. Heuer, M. J. Thomson, and M. Wissuwa, "Genetic and genomic approaches to develop rice germplasm for problem soils," Plant Molecular Biology, vol. 65, no. 4, pp. 547-570, 2007.

[6] H. X. Lin, M. Z. Zhu, M. Yano et al., "QTLs for $\mathrm{Na}^{+}$and $\mathrm{K}^{+}$ uptake of the shoots and roots controlling rice salt tolerance," Theoretical and Applied Genetics, vol. 108, no. 2, pp. 253-260, 2004.

[7] Z. H. Ren, J. P. Gao, L. G. Li et al., "A rice quantitative trait locus for salt tolerance encodes a sodium transporter," Nature Genetics, vol. 37, no. 10, pp. 1141-1146, 2005.

[8] M. J. Thomson, M. Ocampo, J. Egdane et al., "Characterizing the Saltol quantitative trait locus for salinity tolerance in rice," Rice, vol. 3, no. 2-3, pp. 148-160, 2010.

[9] J. D. Platten, J. A. Egdane, and A. M. Ismail, "Salinity tolerance, $\mathrm{Na}^{+}$exclusion and allele mining of HKT1; 5 in Oryza sativa and $O$. glaberrima: many sources, many genes, one mechanism?," BMC Plant Biology, vol. 13, no. 1, p. 32, 2013.

[10] B. B. Patel, B. B. Patel, and R. S. Dave, "Studies on infiltration of saline-alkali soils of several parts of Mehsana and Patan districts of north Gujarat," Journal of Applied Technology in Environmental Sanitation, vol. 1, pp. 87-92, 2011.

[11] N. N. Babu, S. G. Krishnan, K. K. Vinod et al., "Marker aided incorporation of Saltol, a major QTL associated with seedling stage salt tolerance, into Oryza sativa 'Pusa basmati 1121'," Frontiers in Plant Science, vol. 8, 2017. 
[12] E. A. Siddiq, L. R. Vemireddy, and J. Nagaraju, "Basmati rices: genetics, breeding and trade," Agricultural Research, vol. 1, no. 1, pp. 25-36, 2012.

[13] R. K. Ellur, A. Khanna, A. Yadav et al., "Improvement of basmati rice varieties for resistance to blast and bacterial blight diseases using marker assisted backcross breeding," Plant Science, vol. 242, pp. 330-341, 2016.

[14] E. Bienabe and D. Marie-Vivien, "Institutionalizing geographical indications in southern countries: lessons learned from basmati and rooibos," World Development, vol. 98, pp. 5867, 2015.

[15] V. P. Singh, "Basmati rice of India," in Aromatic Rices, R. K. Singh, U. S. Singh and G. S. Khush, Eds., pp. 135-154, Oxford \& IBH Publishing Co. Pvt. Limited, New Delhi, 2000.

[16] S. Gopalakrishnan, R. K. Sharma, K. A. Rajkumar et al., "Integrating marker assisted background analysis with foreground selection for identification of superior bacterial blight resistant recombinants in basmati rice," Plant Breeding, vol. 127, no. 2, pp. 131-139, 2008.

[17] M. Joseph, S. Gopalakrishnan, R. K. Sharma et al., "Combining bacterial blight resistance and basmati quality characteristics by phenotypic and molecular marker assisted selection in rice," Molecular Breeding, vol. 13, no. 4, pp. 377-387, 2004.

[18] A. Khanna, V. Sharma, R. K. Ellur et al., "Development and evaluation of near isogenic lines for major blast resistance gene(s) in basmati rice," Theoretical and Applied Genetics, vol. 128, no. 7, pp. 1243-1259, 2015.

[19] A. Singh, V. K. Singh, S. P. Singh et al., "Molecular breeding for the development of multiple disease resistant basmati rice," AoB Plants, vol. 2012, article pls029, 2012.

[20] R. Aliyu, A. M. Adam, S. Muazu, S. O. Alonge, and G. B. Gregario, "Tagging and validation of SSR markers to salinity tolerance in rice," in 2010 International Conference on Biology, Environment and Chemistry (IPCBEE), vol. 1, pp. 328-332, Singapore, 2011.

[21] T. T. H. Vu, D. D. Le, A. M. Ismail, and H. H. Le, "Markerassisted backcrossing (MA-C) for improved salinity tolerance in rice (Oryza sativa L.) to cope with climate change in Vietnam," Australian Journal of Crop Science, vol. 6, pp. 1649-1654, 2012.

[22] B. D. Singh and A. K. Singh, Marker-Assisted Plant Breeding: Principles and Practices, Springer, New Delhi, 2015.

[23] G. B. Gregorio, M. R. Islam, G. V. Vergara, and S. Thirumeni, "Recent advances in rice science to design salinity and other abiotic stress tolerant rice varieties," SABRAO Journal of Breeding and Genetics, vol. 45, pp. 31-41, 2013.

[24] V. T. Ho, M. J. Thomson, and A. M. Ismail, "Development of salt tolerant IR64 near isogenic lines through marker-assisted breeding," Journal of Crop Science and Biotechnology, vol. 19, no. 5, pp. 373-381, 2016.

[25] L. T. N. Huyen, L. M. Cuc, A. M. Ismail, and L. H. Ham, "Introgression the salinity tolerance QTLs Saltol into AS996, the elite rice variety of Vietnam," American Journal of Plant Science, vol. 3, no. 7, pp. 981-987, 2012.

[26] M. M. Hasan, M. Y. Rafii, M. R. Ismail et al., "Marker-assisted backcrossing: a useful method for rice improvement," Biotechnology and Biotechnological Equipment, vol. 29, no. 2, pp. 237254, 2015.

[27] A. K. Singh, S. Gopalakrishnan, V. P. Singh et al., "Marker assisted selection: a paradigm shift in basmati breeding,"
Indian Journal of Genetics and Plant Breeding, vol. 71, pp. 120-128, 2011.

[28] A. K. Singh and S. G. Krishnan, "Genetic improvement of basmati rice-the journey from conventional to molecular breeding," in Molecular Breeding for Sustainable Crop Improvement. Sustainable Development and Biodiversity, V. Rajpal, S. Rao and S. Raina, Eds., vol. 11, Springer, Cham, 2016.

[29] G. B. Gregorio, D. Senadhira, and R. D. Mendoza, Screening Rice for Salinity Tolerance, IRRI Discussion Paper Series no 22, Los Baños, International Rice Research Institute, 1997.

[30] IRRI, Standard Evaluation System (SES) for Rice, Los Baños, International Rice Research Institute, 5th edition, 2013.

[31] V. K. Singh, V. K. Singh, R. K. Ellur, S. G. Krishnan, and A. K. Singh, "Validation of rapid DNA extraction protocol and their effectiveness in marker assisted selection in crop plants," Indian Journal of Genetics and Plant Breeding, vol. 75, no. 1, pp. 110-113, 2015.

[32] R. Van Berloo, "Computer note. GGT: software for display of graphical genotypes," Journal of Heredity, vol. 90, no. 2, pp. 328-329, 1999.

[33] S. Yoshida, D. A. Forno, J. H. Cock, and K. A. Gomez, Laboratory Manual for Physiological Studies of Rice, International Rice Research Institute, Los Baños, 3rd edition, 1976.

[34] S. H. Basavaraj, V. K. Singh, A. Singh et al., "Marker-assisted improvement of bacterial blight resistance in parental lines of Pusa RH10, a superfine grain aromatic rice hybrid," Molecular Breeding, vol. 26, no. 2, pp. 293-305, 2010.

[35] B. S. Bhargava and H. B. Raghupathi, "Analysis of plant materials for macro and micronutrients," in Methods of Analysis of Soils, Plants, Water and Fertilizers, H. L. S. Tandon, Ed., pp. 49-82, Fertilization Department Consultant Organization, New Delhi, 1993.

[36] IRRI, STAR Version 2.0.1, Biometrics and Breeding Informatics, PBGB Division, International Rice Research Institute, Los Baños, 2014.

[37] N. N. Babu, K. K. Vinod, S. G. Krishnan et al., "Marker based haplotype diversity of Saltol QTL in relation to seedling stage salinity tolerance in selected genotypes of rice," Indian Journal of Genetics and Plant Breeding, vol. 74, no. 1, pp. 16-25, 2014.

[38] V. K. Singh, A. Singh, S. P. Singh et al., "Marker assisted simultaneous but stepwise backcross breeding for pyramiding blast resistance genes Piz5 and Pi54 into an elite basmati rice restorer line 'PRR78',' Plant Breeding, vol. 132, pp. 486-495, 2013.

[39] R. K. Ellur, A. Khanna, S. G. Krishnan et al., "Marker-aided incorporation of $\mathrm{Xa38}$, a novel bacterial blight resistance gene, in PB1121 and comparison of its resistance spectrum with xa13+Xa21," Scientific Reports, vol. 6, no. 1, 2016.

[40] N. N. Babu, K. K. Vinod, S. L. Krishnamurthy et al., "Microsatellite based linkage disequilibrium analyses reveal Saltol haplotype fragmentation and identify novel QTLs for seedling stage salinity tolerance in rice (Oryza sativa L.)," Journal of Plant Biochemistry and Biotechnology, vol. 26, no. 3, pp. 310-320, 2016.

[41] H. Walia, C. Wilson, P. Condamine et al., "Comparative transcriptional profiling of two contrasting rice genotypes under salinity stress during the vegetative growth stage," Plant Physiology, vol. 139, no. 2, pp. 822-835, 2005.

[42] H. Walia, C. Wilson, L. Zeng, A. M. Ismail, P. Condamine, and T. J. Close, "Genome-wide transcriptional analysis of salinity stressed japonica and indica rice genotypes during panicle 
initiation stage," Plant Molecular Biology, vol. 63, no. 5, pp. 609-623, 2007.

[43] J. D. Platten, O. Cotsaftis, P. Berthomieu et al., "Nomenclature for HKT transporters, key determinants of plant salinity tolerance," Trends in Plant Science, vol. 11, no. 8, pp. 372-374, 2006.

[44] A. B. Garcia, J. D. Engler, S. Iyer, T. Gerats, M. Van Montagu, and A. B. Caplan, "Effects of osmoprotectants upon $\mathrm{NaCl}$ stress in rice," Plant Physiology, vol. 115, no. 1, pp. 159-169, 1997.

[45] P. Senadheera, R. K. Singh, and F. J. M. Maathuis, "Differentially expressed membrane transporters in rice roots may contribute to cultivar dependent salt tolerance," Journal of Experimental Botany, vol. 60, no. 9, pp. 2553-2563, 2009.

[46] T. B. De Leon, S. Linscombe, and P. K. Subudhi, "Molecular dissection of seedling salinity tolerance in rice (Oryza sativa L.) using a high-density GBS-based SNP linkage map," Rice, vol. 9, no. 1, article 52, 2016.

[47] R. Mohammadi, M. S. Mendioro, G. Q. Diaz, G. B. Gregorio, and R. K. Singh, "Genetic analysis of salt tolerance at seedling and reproductive stages in rice (Oryza sativa)," Plant Breeding, vol. 133, no. 5, pp. 548-559, 2014. 


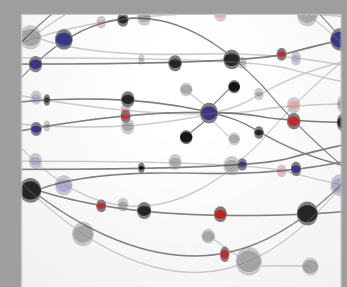

The Scientific World Journal
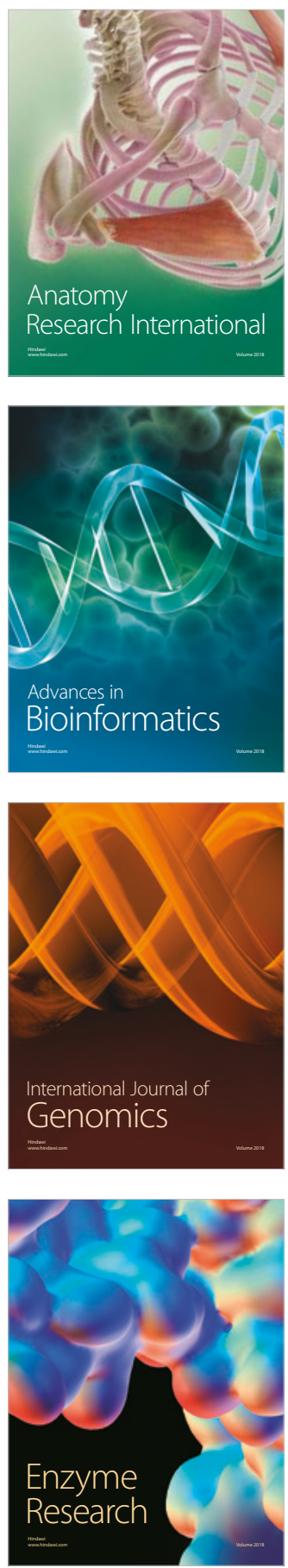
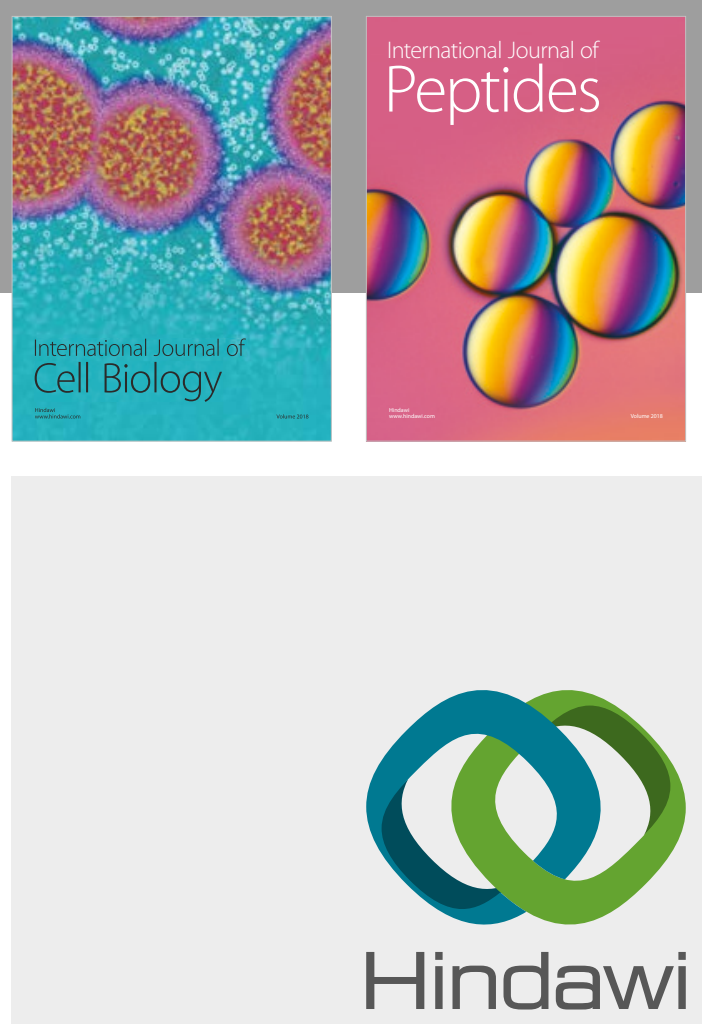

Submit your manuscripts at

www.hindawi.com
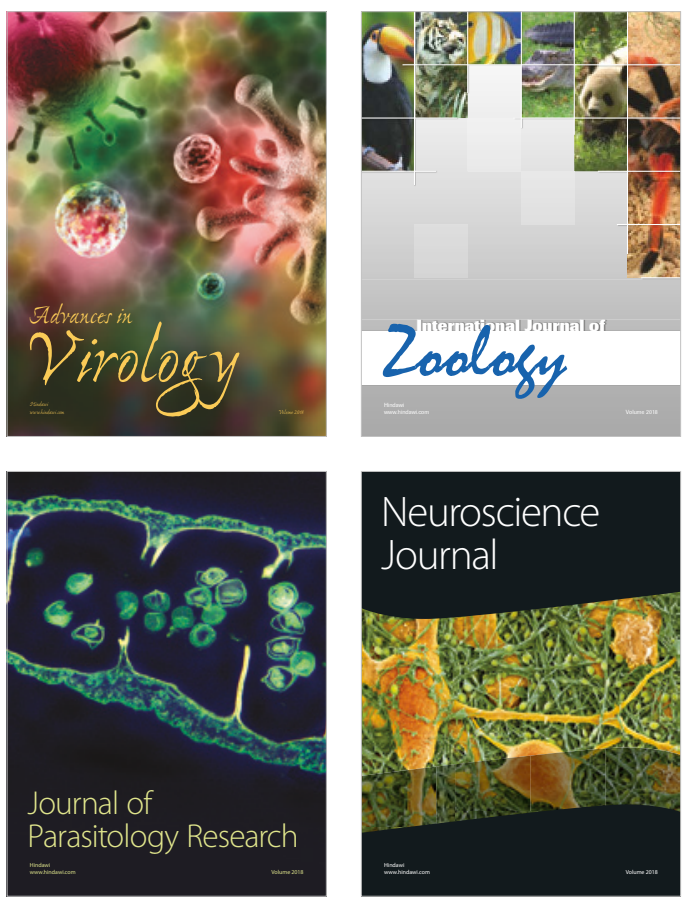
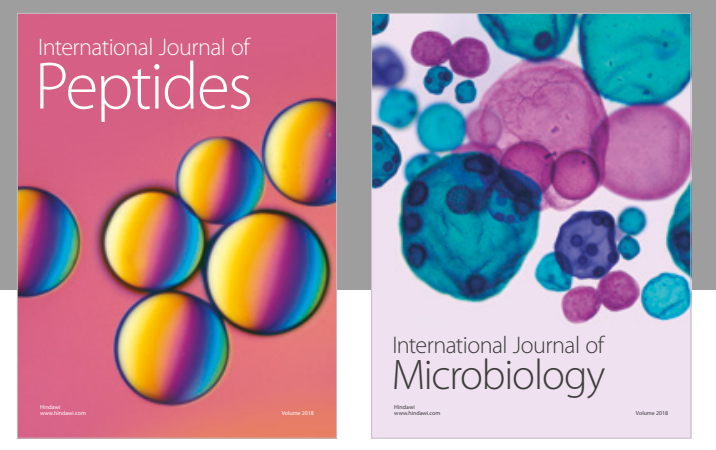

nternational Journal of Microbiology
Journal of
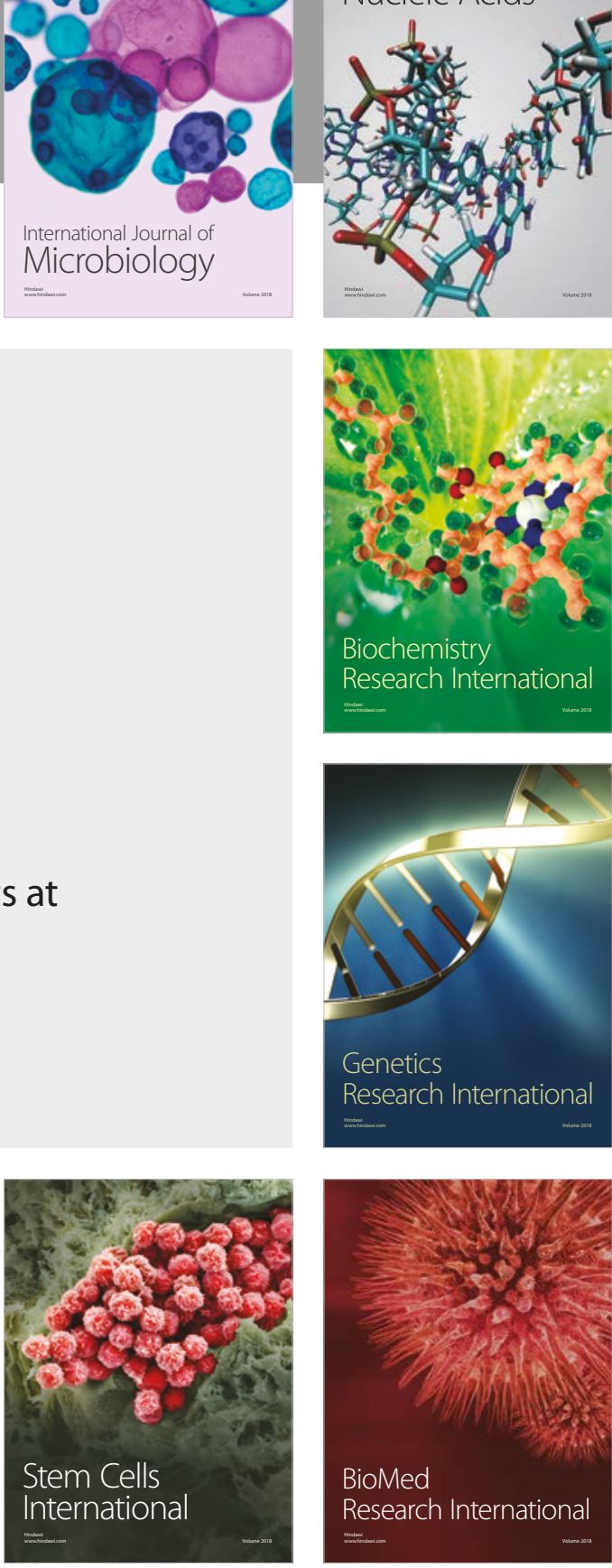
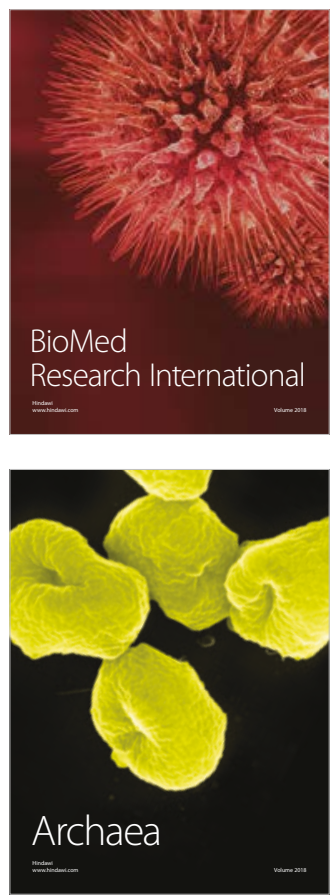